\title{
Moral disciplining: The cognitive and evolutionary foundations of puritanical morality
}

\author{
Léo Fitouchi* \\ Institut Jean Nicod, Département d'études cognitives, ENS, EHESS, PSL University, \\ CNRS, Paris, France \\ *Corresponding author \\ leo.fitouchi@gmail.com \\ https://sites.google.com/view/leofitouchi
}

Jean-Baptiste Andrét

Institut Jean Nicod, Département d'études cognitives, ENS, EHESS, PSL University, CNRS, Paris, France

jeanbaptistrandre@gmail.com

http://jb.homepage.free.fr/

Nicolas Baumard ${ }^{\dagger}$

Institut Jean Nicod, Département d'études cognitives, ENS, EHESS, PSL University, CNRS, Paris, France

nbaumard@gmail.com

https://nicolasbaumards.org/

$\dagger$ These authors contributed equally

\section{Short abstract}

Why do many human societies morally condemn apparently victimless and pleasurable behaviors, such as lust, gluttony, drinking, drugs, gambling, or even music and dance? Why do they morally praise temperance, chastity, sobriety, decency, and piety? While this puritanical morality often appears as an exception to the cooperative function of moral cognition, we propose that it stems, like other moral concerns, from moral judgements targeting cooperative challenges. Specifically, we propose that it consists of preemptive moralizations of behaviors perceived as risk factors for uncooperative self-control failures, impeding people's ability to resist the short-term temptations naturally conflicting with cooperative motivations.

\section{Long abstract}

Why do many societies moralize apparently harmless pleasures, such as lust, gluttony, alcohol, drugs, and even music and dance? Why do they erect temperance, asceticism, sobriety, modesty, 
and piety as cardinal moral virtues? According to existing theories, this puritanical morality cannot be reduced to concerns for harm and fairness: it must emerge from cognitive systems that did not evolve for cooperation (e.g., disgust-based "Purity" concerns). Here, we argue that, despite appearances, puritanical morality is no exception to the cooperative function of moral cognition. It emerges in response to a key feature of cooperation, namely that cooperation is (ultimately) a long-term strategy, requiring (proximately) the self-control of appetites for immediate gratification. Puritanical moralizations condemn behaviors which, although inherently harmless, are perceived as indirectly facilitating uncooperative behaviors, by impairing the selfcontrol required to refrain from cheating. Drinking, drugs, immodest clothing, and unruly music and dance, are condemned as stimulating short-term impulses, thus facilitating uncooperative behaviors (e.g., violence, adultery, free-riding). Overindulgence in harmless bodily pleasures (e.g., masturbation, gluttony) is perceived as making people slave to their urges, thus altering abilities to resist future antisocial temptations. Daily self-discipline, ascetic temperance, and pious ritual observance are perceived as cultivating the self-control required to honor prosocial obligations. We review psychological, historical, and ethnographic evidence supporting this account. We use this theory to explain the fall of puritanism in WEIRD societies, and discuss the cultural evolution of puritanical norms. Explaining puritanical norms does not require adding mechanisms unrelated to cooperation in our models of the moral mind.

Keywords: cooperation, morality, modesty, self-control, sobriety, pleasure, puritanism, purity, temperance, temptation, sin 


\section{Introduction}

Brueghel's 1559 painting The Fight Between Carnival and Lent contrasts the vices and virtues of puritanical moral standards. On one side of the painting, "men and women dance, they crowd into a tavern, get drunk, play games, watch street theatre, ignore beggars, sneak inside for sex, play cruel tricks on others, gamble, eat, join masked processions, and make music; in short, they are unruly, profane, sexually promiscuous, spontaneous, and concerned with immediate gratification" (Martin, 2009, p. 9). On the other side of the painting, other "men and women work, attend church, give alms to beggars and the poor; in short they are orderly, sober, devout, and disciplined" (Martin, 2009, pp. 9-10). This side represents the values of "decency, diligence, gravity, modesty, orderliness, prudence, reason, self-control, sobriety, and thrift”' (Burke, 1978, p. 213).

In recent decades, moral psychologists have identified a related cluster of moral norms. They have noted that many human societies praise chastity, temperance, and piety; condemn the immoderate enjoyment of sensual pleasures; and disapprove of the lack of religious and ritual observance (Graham et al., 2013; Haidt, 2012, 2007; Haidt \& Joseph, 2007; Shweder et al., 1987, 1997). This constellation of moral values gained popularity in psychological and evolutionary approaches to morality as part of the so-called "Purity" moral concerns (Graham et al., 2013; Haidt, 2012, 2007; Haidt \& Joseph, 2004, 2007). The Purity category, however, is a murky concept with no clear definition (Crone, 2022; Gray et al., 2022; Kollareth et al., 2022). Reviewing 158 papers of the Purity literature, Gray et al. (2022) show that moral psychologists understand Purity in about nine different ways, often mixing distinct meanings in their definitions and operationalizations. To avoid confusions, we here use the term puritanical morality (or "puritanism") to refer to the ascetic, austere moralization of apparently victimless pleasures that humans crave for, such as eating, drinking, feasting, dancing, gambling, taking drugs, dressing indecently, having sex, or masturbating.

Puritanical morality, more precisely, comprises the following constellation of moral norms:

1. A moral condemnation of bodily pleasures. Christian morality, for example, condemns excessive indulgence in food and sex as the deadly sins of gluttony and lust (Dabhoiwala, 2012; Hill, 2011; Adamson, 2004). Psychologists have observed that many participants moralize unrestrained or unhealthy eating (Fitouchi et al., 2022; Ringel \& Ditto, 2019; Steim \& Nemeroff, 1995; Mooijman et al., 2018), as well as sexual indulgences such as 
masturbation or oral sex (Fitouchi et al., 2022; Haidt et al., 1993; Haidt \& Hersh, 2001; Schein et al., 2016).

2. A strong valorization of temperance and self-discipline. In various countries, a substantial share of participants moralize lack of self-control (Mooijman et al., 2018), general hedonism (Saroglou \& Craninx, 2021), and reluctance to needless effort (Celniker et al., 2022; Tierney et al., 2021), while similar values are preached across world religions (see section 1.1.). In medieval and early modern Western societies, for instance,

self-discipline in all spheres of life was prized as the ultimate mark of civilization (...) Only beasts and savages gave 'unrestrained liberty' to 'the cravings of nature' - civilized Christians were rather 'to bring under the flesh; bring nature under the government of reason, and, in short bring the body under the command of the soul. The mental and physical government of fleshly appetites was the very foundation of the whole culture of discipline. (Dabhoiwala, 2012, pp. 26-27).

3. Condemnations of entertainments such as alcohol, drug use, gambling, and certain forms of music and dances. These are widespread both in cross-national surveys (Lugo et al., 2013; Poushter, 2014; Weeden \& Kurzban, 2013), and in the explicit moral codes of various societies (e.g. Buddhism: Sterckx, 2005, pp. 223-224; Najjar et al., 2016; Hinduism: Doniger, 2014, pp. 263-270; traditional Europe: Martin, 2009; Wagner, 1997; Burke, 1978; Partridge \& Moberg, 2017; Arab-Muslim societies: Otterbeck \& Ackfeldt, 2012; Michalak \& Trocki, 2006).

4. Moral demands of modesty, which regulate decency in clothing, speech, and attitudes. In traditional Arab-Muslim societies, for example, when entering the public sphere, women must be veiled, lower their gaze, and avoid body ornaments (Antoun, 1968; Beckmann, 2010; Mernissi, 2011), while similar restrictions appear in other puritanical cultures (e.g., Puritans' austere clothing: Bremer, 2009; Hindu India: Stephens, 1972, p. 4; Jewish T₹nibut dress: Andrews, 2010; Ancient Christian veiling: Tariq, 2013).

5. Moral prescriptions of a pious lifestyle, requiring the diligent observance of religious rituals, such as fasting, daily prayers, meditations, effortful pilgrimages, or dietary restrictions (see section 1.1). 
This definition of puritanism comprises many core elements of Purity, which is often defined by moral psychologists as including moralizations of lust, gluttony (Haidt \& Graham, 2007; McAdams et al., 2008), clothing, prayer, meditation, temperance, self-control (Graham et al., 2009; Horberg et al., 2009; Koleva et al., 2012), drugs, alcohol, and certain kinds of music (Helzer \& Pizarro, 2011; Horberg et al., 2009)—all of which are central to puritanism as defined here. However, because of its heterogeneity (Kollareth et al., 2022), the Purity category is broader than puritanism as we define it. In particular, Purity also includes concerns for physical contamination, often operationalized by weird or abnormal behaviors (Gray \& Keeney, 2015; Kupfer et al., 2020), such as pouring urine on oneself (Chakroff et al., 2017), touching poop barehanded (Dungan et al., 2017), or eating pizza off a dead body (Clifford et al., 2015). We do not include this subclass of Purity in our definition of puritanism because, as researchers have noted, these contamination-related concerns appear distinct from those labelled here as puritanical (Crone, 2022; though see Section 6.1.1).

Why, then, do many societies develop puritanical values? Answering this question requires resolving two puzzles.

\subsection{The puzzle of association}

First, puritanism consists of apparently heterogenous moral concerns, governing domains as various as sex, food, clothing, self-discipline, entertainments, and ritual observance. Yet despite their heterogeneity, these moral concerns tend to co-occur and cohere in the most culturally successful moral traditions, which cover almost $80 \%$ of the world's population (Hackett \& McClendon, 2017)—from Hinduism (Doniger, 2014, pp. 363-370; Hatcher, 2017; Menon, 2013; Nag, 1972, p. 236; Stephens, 1972, p. 4; Vatuk \& Vatuk, 1967, pp. 108-112) to Christianity (Bremer, 2009; Burke, 1978; Dabhoiwala, 2012a; Gaca, 2003; Gorski, 2003; Partridge \& Moberg, 2017; Spiegel, 2020a; Wagner, 1997) to Buddhism (Harvey, 2000; Keown, 2003, pp. 78, 93; Mann, 2011; Sterckx, 2005, pp. 223-224; Stunkard et al., 1998) to Chinese religions (Brokaw, 2014; Csikszentmihalyi, 2009; Slingerland, 2014, p. 76; Suiming, 1998; Tiwald, 2020; Yü, 2021, pp. 36-40, 82, 216) to Arab-Muslim societies (Garden, 2014, pp. 83, 89, 76; Mernissi, 2011; Michalak \& Trocki, 2006; Otterbeck \& Ackfeldt, 2012, pp. 231-233; Rehman, 2019) and Ancient Greco-Roman spiritualities (Gaca, 2003; Langlands, 2006).

This association, suggested by qualitative data, is consistent with psychological evidence. Studies find that moralizations of gluttony, sexual indulgences, lack of self-control, intoxicant use, and 
certain types of music, are intercorrelated (Fitouchi et al., 2022; Gay, 2000; Kurzban et al., 2010; Mooijman et al., 2018; Quintelier et al., 2013; Steim \& Nemeroff, 1995; Tierney et al., 2021). Condemnations of lack of self-control, intoxicant use, hedonism, sexual indulgences, and immodesty are all associated with religiosity (Grubbs et al., 2015; Jacquet et al., 2021; Mooijman et al., 2018; Moon et al., 2021; Najjar et al., 2016; Saroglou \& Craninx, 2021; Stylianou, 2004; Weeden \& Kurzban, 2013), which is itself related, across countries, to the moralization of piety (Abrams et al., 2020; Tamir et al., 2020). At a deeper level, experimental evidence indicates that different puritanical norms are intuitively intertwined in people's mind. Experimental studies of "implicit puritanism" across cultures $(N>6000)$ show that Indian, American, Australian, and English participants all implicitly associate violation of one puritanical norm (work-related selfdiscipline) with violations of another puritanical norm (sexual restraint), by misremembering individuals described as violating one norm as also violating the other (Tierney et al., 2021).

Hence the first puzzle of puritanism: Why do moralizations of bodily pleasures, self-discipline, entertainments, clothing, and piety often develop in concert?

\subsection{The puzzle of morality without cooperation}

The second puzzle of puritanical morality concerns its relation to cooperation. Most evolutionary theories of morality share the ultimate hypothesis that moral cognition is an adaptation to the challenges of cooperation recurrent in human social life (Alexander, 1987; André et al., 2022; Baumard et al., 2013; Boehm, 2012; Curry, 2016; Haidt, 2012; Stanford, 2018; Tomasello, 2019). This hypothesis explains the vast majority of moral intuitions and norms found across human societies, such as condemnations of theft, murder, violence, unfairness, and the promotion of justice, loyalty, reciprocity, or respect for property and authority (Baumard, 2016; Boehm, 2012; Curry et al., 2019; Hofmann et al., 2014; Purzycki et al., 2018).

In this context, puritanical morality appears as an "odd corner of moral life" (Haidt \& Joseph, 2004, p. 60). If moral cognition evolved for cooperation, moral condemnations should only target cheating behaviors, such as lying, theft, free-riding, betrayal of coalition partners, or suffering inflicted on innocent people. Yet, the behaviors typically moralized by puritanical values are not, at first sight, clearly related to cooperation. For example, in medieval Christianity (Dabhoiwala, 2012), Neo-Confucian China (Suiming, 1998, p. 16), or Victorian England (Seidman, 1990), indulgence in sexual pleasure is condemned not only when it amounts to 
cheating other people in a cooperative interaction, such as in adultery ${ }^{1}$, but also in a range of victimless manifestations, such as in masturbation, or too frequent or licentious sex within marriage:

A huge body of teaching grew up in support of the notion that bodily desire was inherently shameful and sinful ... Even in marriage, men and women had to be constantly on their guard against sinning through immoderate, unchaste, or unprocreative sex. (Dabhoiwala, 2012, pp. 7-8).

In moral psychology, famous vignettes studies have echoed this apparent harmlessness of sexual sins, finding that American and Brazilian participants condemn "purity violations," such as masturbating in a chicken carcass, even though these actions do not in themselves cause any harm to other individuals (Haidt et al., 1993; Haidt \& Hersh, 2001; Horberg et al., 2009).

Similarly, puritanical values condemn immoderate indulgence in food pleasure, even when gluttony doesn't involve failing in one's duty to share food, or to respect others' property (e.g., Medieval Christianity: Hill, 2011; Adamson, 2004; India: Vatuk \& Vatuk, 1967; European Antiquity: Coveney, 2006; Gaca, 2003). The Christian sin of gluttony, for example, condemns the failure to control the food appetite in itself-whether by eating too much, failing to wait for the proper time to eat, eating too eagerly, or craving foods that are too tasty (Adamson, 2004; Hill, 2007, 2011). Psychologists, too, observe that participants moralize inherently harmless eating practices, such as eating fatty rather than healthy foods (Fitouchi et al., 2022; Mooijman et al., 2018; Oakes et al., 2004; Steim \& Nemeroff, 1995).

Besides food and sex, puritanical values prescribe industrious self-discipline even when idleness would be harmless and effort unproductive (Indian, American, Australian, and English

\footnotetext{
${ }^{1}$ Adultery is an instance of cheating in the context of pair-bonding and marriage-a cooperative interaction on reproduction, resource production, and parental investment (Gurven et al., 2009). Committed pair-bonds enjoy mutual benefits of parental certainty and greater efficiency in child care (Chapais, 2009; Gurven et al., 2009). Yet, just as in other cooperation dilemmas (Rand \& Nowak, 2013), they also face short-term incentives to cheat by taking advantage of their partner's exclusive provision of benefits (fidelity), while not reciprocating it to reap the benefits of extra-pair mating (see Buss \& Schmitt, 1993; Gangestad \& Simpson, 2000). Adultery, thus, amounts to take the benefits of one's partner cooperation (fidelity) while not oneself paying the costs of cooperation (by oneself remaining faithful) and is accordingly nearly universally condemned (Broude \& Greene, 1976; Murdock, 1949; Poushter, 2014). This is not to deny the often-patriarchal nature of adultery proscriptions, which often sanction female's infidelity more strongly than male adultery (Broude \& Greene, 1976), and often take the form of prohibitions for men to steal each other's wife, treating women as the property of their husband, father, or brothers (Dabhoiwala, 2012a, p. 5). Such patriarchal norms are likely grounded in males' interests to police female sexuality (see section 2.2.).
} 
participants: Tierney et al., 2021; Uhlmann et al., 2011; American and South-Korean participants: Celniker et al., 2022; Early modern China: Yü, 2021). They condemn alcohol, drugs, and gambling, when the latter are widely considered "victimless crimes" (Boyd \& Richerson, 2001; Ellis, 1988; Stylianou, 2010). And their strict regulations of mundane activities, such as music, dance, or clothing appear, to our modern eyes, as needlessly austere restrictions (see Moon et al., 2021).

Hence the second puzzle of puritanism: If the function of morality is cooperation-as the prominence of cooperative norms in the human moral landscape suggests (Curry, Mullins, et al., 2019; Hofmann et al., 2014; Purzycki et al., 2018)—why do humans moralize victimless lifestyle choices with respect to sex, food, drinking, clothing, self-discipline, and ritual observance?

This apparent disconnect between puritanical morality and cooperation has sparked intense debates about the cognitive architecture of morality, opposing unitary models of moral cognition to theories dividing morality into distinct cognitive domains (Beal, 2020; Graham et al., 2013; Schein \& Gray, 2018). Unitary theories argue that all moral judgements are produced by a single, functionally unified cognitive mechanism. In particular, the Theory of Dyadic Morality maintains that all moral judgements stem from perceptions of dyadic harm-i.e., from perceptions that an 'agent' intentionally causes suffering to a 'patient' (Gray et al., 2012, 2014; Schein \& Gray, 2015, 2018). Other unitary theories argue that all moral judgements are outputs of fairness computations, tracking violations of mutual benefit between cooperative partners (André et al., 2022; Baumard, 2016; Fitouchi et al., 2021b)². By contrast, theories based on distinct cognitive domains_-such as Moral Foundations Theory—maintain that moral cognition is composed of multiple, functionally distinct, domain-specific mechanisms, some of which track stimuli unrelated to harm or fairness (Graham et al., 2013). In these debates, Purity moralizations have appeared as critical arguments against unitary theories. If harmless behaviors can be morally condemned, scholars have argued, there must be in the mind some mechanisms that generate moral judgements despite not functioning for cooperation (Haidt, 2012). Accordingly, puritanical morality has so far been explained by psychological mechanisms unrelated to cooperation, such as pathogen-avoidance and conflicts of reproductive interests (see section 2).

\footnotetext{
${ }^{2}$ Not all cooperation-based theories of morality are unitary, and not all unitary theories are cooperationbased. Some theories, such as the Morality-As-Cooperation framework (Curry, 2016), view morality as functioning entirely for cooperation, yet slice morality into multiple domains corresponding to distinct domains of cooperation (see also Cosmides et al., 2018). Conversely, some theories maintain that morality did not evolve for cooperation, but rather to advance condemners' self-interest, yet regard morality as a functionally unitary cognitive mechanism (DeScioli \& Kurzban, 2009, 2013).
} 


\subsection{The moral disciplining theory of puritanism}

Here, we propose that puritanical morality does target cooperation, and is reducible to concerns for harm or fairness. Psychologists and evolutionary scientists have long noted that reciprocal and reputation-based cooperation require self-control — the ability to delay gratification, by resisting temptations of immediate rewards (Axelrod, 1984; Ainslie, 2013; Manrique et al., 2021; Stevens et al., 2005; Hofmann et al., 2018). Historians and social scientists, meanwhile, have repeatedly stressed that puritanical groups seem obsessed with the cultivation of self-control (Csikszentmihalyi, 2009; Dabhoiwala, 2012; Eisner, 2014; Gaca, 2003; Gorski, 2003; Luttmer, 2000; Menon, 2013; Oestreich, 1982; Rehman, 2019; Seidman, 1990; Spiegel, 2020; Walzer, 1963, 1982; Weber, 1968; Yü, 2021). Connecting these insights, we propose that puritanism develops from folk-psychological beliefs that restraining indulgence in victimless pleasures would improve people's self-control, thus facilitating cooperative behaviors.

Our argument goes as follows. People perceive that meeting prosocial obligations often requires self-control (section 3.1.) Refraining from violent behaviors, they perceive, sometimes requires resisting aggressive impulses. Abstaining from adultery sometimes requires resisting sexual temptations. In collective work, doing one's fair share of effort can require overcoming lazy desires. Meanwhile, people perceive, not only that cooperation requires self-control, but also that some behaviors alter self-control (section 3.2.). They perceive that alcohol and drugs make people impulsive, precipitating antisocial behaviors— such as adultery, violence, or lazy free-riding-by impeding abilities to resist impulses. They see carnal pleasures—lust, gluttony, intoxicants, gambling - as dangerously addictive behaviors, overindulgence in which would make people slave to their urges, and unable to resist uncooperative temptations. By contrast, daily selfdiscipline, ascetic temperance, and regular ritual observance are perceived as improving people's self-control, thus ensuring that they remain peaceful neighbors, faithful husbands and wives, industrious workers, responsible family members, or conscientious followers. Thus, while inherently harmless, hedonistic behaviors are perceived as indirectly socially harmful. As such, they are naturally tagged as morally wrong by cognitive systems biologically evolved to detect and condemn uncooperative behaviors or threats to cooperation (section 3.3.). Puritanical moral judgements are thus generated by the same, cooperation-based cognitive systems producing the rest of human morality. 
These intuitive psychological processes, in turn, shape the cultural evolution of puritanical norms (section 3.4.). In environments where many people want to prevent perceived antisocial effects of hedonistic impulses, people gradually invent and refine cultural technologies they perceive as efficient for disciplining other individuals to ensure social order. These technologies of moral selfdiscipline include ascetic rituals, modest clothes, legal regulations of entertainment such as drinking and feasting, as well as mental techniques for the self-monitoring of impulses (see section 6.1.2). Our account, importantly, is agnostic as to whether puritanical norms are objectively effective in improving self-control and cooperation-it rather insists on people's perceptions that they are.

In the following, we first review and examine existing accounts of puritanical morality (Section 2). Section 3 lays out the evolutionary and psychological foundations of the moral disciplining theory of puritanism, and reviews evidence for its assumptions. We then derive predictions from this account, review current evidence supporting them, and outline avenues for further testing (Section 4). We finally use this theory to explain the fall of puritanism in WEIRD societies (Section 5), and discuss extensions and outstanding questions for the study of puritanical values (Section 6).

\section{Existing accounts of puritanical morality}

\subsection{Moral Foundations Theory and disgust-based accounts}

Moral Foundations Theory considers puritanical morality as an exception to the cooperative function of moral cognition (Graham et al., 2013; Haidt, 2012; Haidt \& Joseph, 2007). According to this framework, moral cognition is composed of several domain-specific cognitive systems, most which have evolved for cooperative adaptive challenges—including Harm/Care, Fairness/Reciprocity, Loyalty/Betrayal, and Authority/Respect. The last moral system, Purity/Sanctity, is instead proposed to function for the non-social challenge of pathogenavoidance, and to emerge from disgust at the proximate level (Haidt \& Joseph, 2007). People driven by carnal impulses rather than spiritual motivations would be detected by this disgustrelated system as "impure" and "less than human," and thus morally condemned (Haidt \& Graham, 2007, p. 9). While this theory is consistent with the frequent cultural depiction of pleasure-seeking behaviors as "impure," it seems insufficient to explain puritanical morality, for at least two reasons. 
First, it is unclear that violations of puritanical standards actually trigger disgust. Initial support for this hypothesis came from "purity violation" studies, in which participants find apparently harmless behaviors (e.g., masturbating in a chicken carcass) both disgusting and morally wrong (e.g. Haidt et al., 1993; Haidt \& Hersh, 2001; Horberg et al., 2009; Rozin et al., 1999). However, containing more pathogen cues than the typical targets of puritanical moralizations, such vignettes appear disconnected from real-world puritanical concerns. As such, they are likely to overestimate the extent to which real-world violations of puritanical standards evoke disgust. For example, in widely cited studies, sexual lust takes the form of masturbating in a dead chicken (Haidt et al., 1993; Horberg et al., 2009) or corpse-sexing (Haidt \& Hersh, 2001). Gluttony becomes eating one's dead dog (Haidt et al., 1993), or rotten meat (Rozin et al., 1999). By contrast, historical and anthropological data make clear that puritanical societies are less morally obsessed by disgusting sexualities with dead animals than with the sin of lust as the unbridled craving for sexual pleasure (Dabhoiwala, 2012; Gaca, 2003; Le Goff, 1984; Mernissi, 2011; Seidman, 1990). For example, medieval Christian moralists (e.g., Augustine, $4-5^{\text {th }}$ c., Aquinas, $13^{\text {th }}$ c.) regarded the peculiar problem of the sin of lust to be "the intensity of the pleasure it offers" (Sweeney, 2012, p. 96), and its resulting "unparalleled power to overwhelm reason and human will” (Dabhoiwala, 2012 , p. 8). In the same vein, the sin of gluttony condemns the immoderate indulgence in the pleasure of eating (Adamson, 2004; Bynum, 2000; Hill, 2007, 2011), not the eating of rotten aliments or animal corpses. In fact, pleasurable aliments (affording gluttony) are almost by definition aliments that are not disgusting. In line with these ideas, when participants are asked to themselves generate sinful or lustful scenarios, they overwhelmingly mention pathogen-free behaviors (e.g., stripping) (Gray \& Keeney, 2015).

Aside from lust and gluttony, moralizations of intemperance, lack of self-discipline, and impiety also seem unrelated to disgust. These behaviors do not involve pathogen-cues at all. Accordingly, maintaining that disgust explains their condemnation has required to argue that this emotion is triggered not only by pathogen cues, but also by "spiritually" impure behaviors, that "degrade" the elevated nature of the human soul or remind humans of their "animal nature" (Haidt \& Graham, 2007; Rozin et al., 1999, 2008; Rozin \& Haidt, 2013)—an often contested theory (Bloom, 2013; Royzman \& Sabini, 2001; Tybur et al., 2013). As many researchers have noted, self-reports of being “disgusted” by "spiritual impurities" (Ritter et al., 2016) do not reliably demonstrate that the cognitive system of disgust is actually activated. The lay meaning of the term "disgust" is difficult to disentangle from "anger" or "contempt" (Herz \& Hinds, 2013; Nabi, 2002; Piazza et al., 2018), and people likely use the term metaphorically to communicate 
their disapproval (Armstrong et al., 2020; Bloom, 2004; Nabi, 2002; Royzman \& Sabini, 2001; Royzman \& Kurzban, 2011). In line with this idea, pathogen-free violations of "spiritual purity" are not associated with the facial expression of disgust (Franchin et al., 2019; Ritter et al., 2016); do not elicit a disgust-related phenomenology (nausea, gagging, loss of appetite), nor action tendency (desire to move away) (Royzman et al., 2014); and are not or negligibly associated with reporting being "grossed-out” (Kollareth et al., 2022; Kollareth \& Russell, 2019)— the lay term more aptly capturing the cognitively strict sense of disgust (Herz \& Hinds, 2013; Nabi, 2002).

Second, disgust-based accounts of puritanism rely on the premise that simply perceiving an action as disgusting is sufficient to judge it immoral. As researchers have noted, however, many behaviors are disgusting without being immoral (Kayyal et al., 2015; Piazza et al., 2018; Pizarro et al., 2011; Schein et al., 2016). It seems, moreover, evolutionarily unclear why disgust should have acquired such a secondary moralizing function (Fitouchi et al., 2021b), and the experimental evidence seems overall to cast doubt on this possibility (Piazza et al., 2018, for an extensive review). In particular, a meta-analysis (Landy \& Goodwin, 2015), highly powered replications (Ghelfi et al., 2020; Johnson et al., 2016), and recent studies (Jylkkä et al., 2021) strongly suggest that feelings of disgust do not increase moral condemnation, nor cause moralization of otherwise morally neutral actions. Relatedly, correlations between disgust-sensitivity and condemnations of sex- and purity-related behaviors (Crawford et al., 2014; Horberg et al., 2009; Inbar et al., 2009) have been found to disappear when perceptions of harm are controlled for (Schein et al., 2016; see also Gray et al., 2014; Gray \& Schein, 2016), and seem partly due to the more general effect of affective states (not only disgust) on a wide range of (not only moral) judgments (Cheng et al., 2013; Landy \& Piazza, 2017).

\subsection{Self-serving norms and conflicts of sexual strategies}

An important framework posits that moral cognition evolved not to promote cooperation, but to advance the condemner's self-interest, by recruiting allies to condemn enemies, coordinating side-taking in conflicts, and promoting moral norms advantageous to oneself (DeScioli, 2016; DeScioli et al., 2014; DeScioli \& Kurzban, 2009, 2013; Petersen, 2018; Sznycer et al., 2017; Tooby \& Cosmides, 2010). Within this framework, researchers argue that some puritanical norms emerge from self-serving attempts by some individuals to promote their reproductive interests at the expense of others' (Kurzban et al., 2010; Weeden et al., 2008; Weeden \& Kurzban, 2016). The Reproductive Religiosity Model argues that a high level of promiscuity in the environment threatens monogamous individuals' ability to reap the benefits of their 
committed, parentally investing reproductive strategy, by increasing the risk of cuckoldry or mate-poaching (Weeden \& Kurzban 2016). Monogamous individuals, thus, have an interest in normatively curbing sexual promiscuity. Researchers also argue that males' attempts to control female sexuality explain values of female chastity and modesty, and restrictions aimed at increasing paternity certainty, such as veiling, virginity tests, female claustration, and menstrual taboos (Becker, 2019; Blake et al., 2018; Dickemann, 1981; Pazhoohi et al., 2017; Strassmann et al., 2012; Strassmann, 1992).

These accounts are not incompatible with the one with propose. Mate-guarding surely underly many sexual restrictions (Strassmann et al., 2012), and is consistent with the frequent doublestandard favoring men in the moralization of sexuality (Broude \& Greene, 1976; Dabhoiwala, 2012b). Consistent with the Reproductive Religiosity Model, monogamous individuals more harshly oppose sexual promiscuity (Weeden \& Kurzban, 2016) and its facilitators (e.g., drugs; Kurzban et al., 2010; Quintelier et al., 2013), and seem to use religion to facilitate and encourage monogamous pair-bonding (Baumard \& Chevallier, 2015; Jacquet et al., 2021; Moon, 2021; Moon et al., 2019; Weeden et al., 2008; Weeden \& Kurzban, 2013).

However, these accounts fail to sufficiently explain the more general condemnation of hedonic excesses beyond sexuality, such as gluttony (Hill, 2011; Steim \& Nemeroff, 1995), drinking, harmless idleness (Tierney et al., 2021), or general lack of self-discipline (Mooijman et al., 2018) — sexual lust is only one of the many pleasure-seeking tendencies that puritanical morality condemns. They also do not account for the condemnation of bodily pleasures as intrinsically sinful, even when they are truly harmless to males or monogamous strategists, such as in frequent sexuality between monogamous, married partners (e.g. Dabhoiwala, 2012, pp. 7-9; Seidman, 1990; Suiming, 1988, p. 16), or in solitary masturbation (Seidman, 1990). Besides, puritanical societies moralize not only female lust but male sexual desires as well-an observation inconsistent with the mate-guarding hypothesis (Muslim Zanzibar: Beckmann, 2010; Medieval and early modern Europe: Dabhoiwala, 2012, p. 8; McIntosh, 2002, pp. 73-74; Victorian England: Seidman, 1990).

While manipulative use of moral discourse is surely used to justify oppressive norms (Strassmann et al., 2012), and advance condemners' self-interests (DeScioli et al., 2014; Sznycer et al., 2017), we propose, in the following, that people genuinely perceive puritanical norms as mutually beneficial in the social contexts in which they prevail. 


\section{The moral disciplining theory of puritanism}

We propose that hedonistic behaviors, although inherently victimless, are condemned because they are perceived as indirectly favoring uncooperative behaviors (e.g., aggression, infidelity, freeriding), by altering people's self-control. This hypothesis assumes that people perceive cooperation as requiring self-control (3.1); that people perceive hedonistic behaviors, such as intoxicant use, bodily pleasures, and undisciplined lifestyles, as reducing people's self-control (3.2.); and that moral cognition is triggered not only by intrinsic instances of cheating, but also by behaviors perceived to indirectly and probabilistically favor socially harmful outcomes (3.3.).

\subsection{People perceive that cooperation requires self-control}

Before reviewing evidence that people perceive self-control as necessary for cooperative behavior (section 3.1.3.), we argue that this intuition is somewhat justified: central forms of human cooperation—-reciprocal and reputation-based cooperation—objectively require delaying gratification (sections 3.1.1. and 3.1.2.). This objective relationship between cooperation and selfcontrol allows explaining why people perceive that cooperation requires self-control in the first place.

\subsubsection{Reciprocal and reputation-based cooperation require delaying gratification}

Cooperation refers to any behavior that benefits another individual (the recipient), and the evolutionary function of which is, at least in part, to benefit the recipient (West et al., 2007, 2011). Some types of cooperation provide immediate inclusive fitness benefits to the actor. This is the case of kin-altruism, whereby the actor automatically increases his indirect fitness (Hamilton, 1964). This is also the case of by-product mutualisms (West et al., 2011), or cooperation for "shared interests" (West et al., 2021), whereby the actor benefits the recipient as a by-product of pursing his own immediate self-interest (e.g., cooperative hunting in social carnivores; Leimar \& Connor, 2003; Leimar \& Hammerstein, 2010).

When the actor's and the recipient's immediate interests are not fully aligned, however, cooperation requires the actor to invest an immediate cost (to benefit the recipient), that is rewarded only in the future, by greater benefit-provision (or reduced cost-infliction) from the recipient or third-parties—such as through direct reciprocity (Axelrod, 1984; Trivers, 1971), indirect reciprocity (Nowak \& Sigmund, 2005; Panchanathan \& Boyd, 2004), or partner choice 
(Barclay, 2013; Roberts, 2020). In the iterated Prisoner's Dilemma, for example, reciprocal cooperation yields higher payoff than defection only in the long run, by securing partners' willingness to reciprocate in subsequent rounds-in the immediate present of each round, cheating pays more than cooperating (Axelrod \& Hamilton, 1981; Axelrod, 1984). Using evolutionary simulations, Roberts (2020) shows that the same holds for cooperation under reputation-based partner choice: cooperation is adaptive when the cost of renouncing the immediate benefit of cheating is exceeded, in the long run, by the increased probability of being chosen as a partner in subsequent interactions. In other words, because people selectively associate with trustworthy partners, a good reputation can be understood as a capital that yields future benefits at each time step of the rest of an individual's life. Damaging this capital by exploiting others brings immediate benefits (e.g., more resources, sexual opportunities, less effort), yet deprives oneself of all the benefits that a good reputation could have brought at each later time-point, by attracting others' cooperative investments (Lie-Panis \& André, 2022).

Accordingly, scholars have widely noted that reciprocal and reputation-based cooperation require delaying gratification: individuals must renounce the immediate, smaller reward of cheating to secure the future, larger benefits of cooperating (R. M. Axelrod, 2006; Frank, 1988; Manrique et al., 2021; Roberts, 2020; Stevens et al., 2005). Lie-Panis \& André (2022) develop a formal understanding of this idea. In their model, individuals are characterized by a discount rate, and engage in numerous Trust Games during their lifetime, with a certain probability of being observed by others, who transmit reputational information impacting future partner choice. At equilibrium in their model, individuals who cooperate are those who are sufficiently futureoriented, i.e., who discount the future benefit of having a good reputation in the rest of their life little enough for this benefit to outweigh the immediate cost of cooperation.

\subsubsection{Cooperation and self-control at the proximate level}

In line with the fact that reciprocal and reputation-based cooperation ultimately require delaying gratification, psychologists have long noted that self-control— the ability to resist temptations of immediate rewards - is likely involved in cooperative decision-making (Ainslie, 2013; Hofmann et al., 2018; Manrique et al., 2021; Stevens et al., 2005). For example, when faced with an attractive mating opportunity, avoiding cheating one's partner requires resisting temptations of immediate sexual pleasure (see Gailliot \& Baumeister, 2007). By renouncing this immediate reward, one secures the long-term benefit of preserving one's pair-bonding relationship-a 
particular type of cooperative interaction (Gurven et al., 2009) —, as well as one's reputation as a trustworthy partner. Meeting obligations to share resources with others, similarly, requires resisting the immediate reward of consuming these resources for oneself (Hofmann et al., 2018; Sebastián-Enesco \& Warneken, 2015). By resisting this temptation, one secures the larger, future benefits of ensuring reciprocal help, as well as a good reputation. Similarly, avoiding interpersonal conflicts sometimes requires overriding aggressive impulses (see Barton-Crosby \& Hirtenlehner, 2021); and doing one's part in collaborative work requires renouncing immediate leisure or procrastination. We call (i) "temptations to cheat" these impulses for immediate rewards (e.g., food, sex, rest) that conflict with prosocial obligations, and (ii) "moral self-control" the resistance to these temptations to cheat (following Hofmann et al., 2018).

Converging lines of evidence demonstrate this importance of self-control for a wide range of cooperative behaviors. Performance on a delay of gratification task predicts children's propensity to share resources with others, after controlling for age (Sebastián-Enesco \& Warneken, 2015). Focusing on the future rather than immediate consequences of their behaviors makes participants more likely to share with others (Sjåstad, 2019), and less likely to behave unethically (Hershfield et al., 2012; van Gelder et al., 2013; Vonasch \& Sjåstad, 2021). Consistent with a trade-off between the immediate benefit of cheating and its future reputational cost, these associations between cooperation and future-orientation are mediated by reputational concern (Sjåstad, 2019; Vonasch \& Sjåstad, 2021). Disrupting participants’ right lateral prefrontal cortex —implied in the self-control of impulses for instant rewards (Kober et al., 2010)—makes participants more likely to cheat in cooperative interactions (Knoch et al., 2009; Knoch \& Fehr, 2007; Ruff et al., 2013; Soutschek et al., 2015; Strang et al., 2015). Following 1,000 children from birth to age 32, Moffitt et al. (2011) show that children with poor self-control are more likely to be convicted of a criminal offense as adults, after controlling for social class origins and IQ. Meta-analytic evidence confirms that low self-control is associated with criminal behaviors (Vazsonyi et al., 2017), lower propensity to forgive others and refrain from retaliation (Burnette et al., 2014; Liu \& Li, 2020), and poorer interpersonal functioning (e.g., loyalty) (de Ridder et al., 2012). Low self-control predicts greater propensity to deceive others to obtain more benefits (Fan et al., 2020), lower likelihood to keep promises in relationships (Peetz \& Kammrath, 2011), as well as uncooperative behaviors in the workplace (e.g., low accommodation of coworkers' needs) (Cohen et al., 2014; Restubog et al., 2010). Regarding sexual cheating, low conscientiousness - a construct related to self-control (Duckworth \& Seligman, 2017)—predicts greater likelihood of infidelity in men and women across 52 countries of 10 world regions 
(Schmitt, 2004; see also Pronk et al., 2011). And studies suggest that intensity of sexual desire, as well as tendencies to notice attractive alternative partners, predict greater infidelity among people with low, but not high dispositional self-control (Brady et al., 2020; McIntyre et al., 2015).

Despite this wealth of evidence, the self-control-requirement of cooperation has been questioned by results from economic games, where meta-analytic evidence finds no association between self-control and cooperation (Thielmann et al., 2020). Studies also found that American participants cooperate more when forced to decide quickly than when forced to delay their decision-suggesting that cooperation in economic games, rather than requiring self-control, may be spontaneous and effortless (Rand, 2016, 2017; Rand et al., 2012). However, this "intuitive cooperation" effect failed to replicate in several, highly powered replications (Bouwmeester et al., 2017; Camerer et al., 2018; Fromell et al., 2020; Isler et al., 2021). Recent evidence indicates that, while cooperating in economic games may be prosocial individuals' spontaneous impulse, the reverse is true for more selfish individuals, in which deliberation increases cooperation — consistent with a role of self-control (Alós-Ferrer \& Garagnani, 2020; Andrighetto et al., 2020; Nockur \& Pfattheicher, 2021; Yamagishi et al., 2017). As Thielmann et al. (2021) note, this moderation by prosocial disposition may have obscured the relationship between self-control and cooperation in their meta-analysis of economic games (pp. 62-63). Field experiments also suggest that economic games underestimate the involvement of self-control in real-life cooperative decisions. Studying Brazilian fishermen living from their catch from a common lake, Fehr \& Leibbrandt (2011) found that, while impulsivity was not associated lower cooperation in an economic game, it did predict likelihood to free-ride on the common-pool resource in real life.

\subsubsection{People perceive that cooperation requires self-control}

Our account of puritanism assumes that people intuitively perceive this self-control-requirement of cooperation - a premise that is well supported. Lie-Panis \& André (2022) show that, because ability to delay gratification enables higher levels of cooperation, it can evolve into a credible signal of trustworthiness. Psychological evidence confirms that, in interaction with strangers as well as in established relationships, people infer others' self-control from their behavior, and expect individuals they perceive as more self-controlled to behave more cooperatively (Buyukcan-Tetik et al., 2015; Buyukcan-Tetik \& Pronk, 2021; Gai \& Bhattacharjee, 2022; Gomillion et al., 2014; Koval et al., 2015; Peetz \& Kammrath, 2013, 2013; Righetti \& 
Finkenauer, 2011). People's intuitions about a good moral character include traits arguably related to self-control, such as being principled or responsible (Goodwin et al., 2013; Goodwin, 2015). And many societies consider self-control, self-discipline, or self-restraint, as key virtues inherent to a good moral character (e.g., Lybian Bedouins: Abu-Lughod, 2016, pp. 90-93; Buddhism: Clark, 1932, pp. 86-88; Goodman, 2017; Confucianism: Csikszentmihalyi, 2020; Tiwald, 2020; Sunni Islam: el-Aswad, 2014; Wolof: Irvine, 1974, pp. 126-127; Zanzibar: Beckmann, 2010, p. 620; Christianity: Spiegel, 2020).

\subsection{People perceive that some behaviors alter self-control}

People, thus, intuit that cooperation requires self-control. We argue that puritanical moral judgements emerge from the interaction of this intuition with folk-psychological beliefs that some behaviors alter self-control. These behaviors include consuming intoxicants (e.g., alcohol, drugs), exposing oneself to tempting environments (e.g., immodest clothes, unruly music and dances), overindulging in potentially addictive pleasures (e.g., food, sex, intoxicants), or pursuing undisciplined lifestyles (e.g., intemperance, idleness, lack of ritual observance). The moral disciplining theory posits that these behaviors are moralized when perceived as undermining people's ability to control their impulses, to the point of endangering compliance with their cooperative obligations. This section characterizes the folk-psychological beliefs which, we propose, underly puritanical moral judgements.

\subsubsection{Lay theories of modifiers of state-self-control}

Some behaviors of the puritanical constellation, we argue, are perceived as altering self-control as a state- that is, the ability to resist temptation in a given moment. We call them "modifiers of state-self-control".

Intoxicants. A first perceived modifier of state-self-control is intoxicant use. Psychological evidence shows that people widely believe alcohol to cause loss of self-control (Brett et al., 2016; Critchlow, 1986; Leigh, 1987). Studies similarly suggest that people perceive drug use as enhancing short-term impulses (Quintelier et al., 2013). These lay theories likely stem from observation of intoxicants' objective psychological effects. Alcohol actually impairs the inhibition of impulses (Heatherton \& Wagner, 2011), narrows attention to cues of immediate rewards-an effect known as "alcohol myopia" (Giancola et al., 2010)_, and fuels a range of impulsive behaviors (e.g., reactive aggression: Duke et al., 2018; Gan et al., 2015; Parrott \& Eckhardt, 2018; 
sexual impulsivity: Rehm et al., 2012; economic impulsivity: Schilbach, 2019). Consumption of drugs is similarly associated with impulsivity (Duke et al., 2018; Nemoto et al., 2007; Weafer et al., 2014).

The moral disciplining theory thus posits that intoxicants are moralized because they are perceived as favoring uncooperative behaviors, such as aggression, infidelity, and general negligence of obligations, by leading people to lose control over immediate impulses, and fueling disregard of future consequences. This hypothesis contrasts with existing accounts, which ignore cooperative concerns in the moralization of intoxicants, by arguing that their moralization stems from disgust-based concerns for the "purity of the soul" (Clifford et al., 2015; Henderson \& Dressler, 2019; Horberg et al., 2009; Silver, 2020), or from exclusively selfish attempts of monogamous strategists to limit sexual promiscuity specifically (Kurzban et al., 2010).

Immodesty as cue exposure. Beside intoxicants, people perceive that self-control is also threatened by exposure to stimuli triggering short-term-oriented impulses-an effect called cueexposure (Heatherton \& Wagner, 2011). Animal brains evolved reward systems tracking stimuli contributing to reproductive success (e.g., food items, sexual opportunities). Environmental cues predicting such items' availability in the immediate environment (e.g., sexual cues, appetizing smell) are thus rapidly learned and imbued with "wanting” properties (Duckworth, Gendler, et al., 2016; Hyman, 2007; Kringelbach \& Berridge, 2009). Exposure to these cues thus generates strong urges to consume the reward in the here and now, pushing individuals toward immediate gratification at the expense of long-term goals (Boswell \& Kober, 2016; Demos et al., 2012; Fujita, 2011; Heatherton \& Wagner, 2011).

People have a folk-understanding of cue-exposure. Early in development, children understand that distracting their attention away from tempting cues (e.g., the marshmallow in front of them) allow them to delay gratification more easily (Carlson \& Beck, 2001; Mischel \& Mischel, 1983; Peake et al., 2002; Sethi et al., 2000). Also witnessing this folk-understanding, people develop "situational" strategies for self-control, rearranging their environment upstream (e.g., by not storing tempting snacks at home) to prevent short-term impulses to be triggered by cue-exposure (Duckworth, Gendler, et al., 2016; Duckworth, White, et al., 2016; Milyavskaya et al., 2020). This folk-understanding, we argue, has moral consequences when cue-exposure is perceived as endangering, not personal self-control (e.g., resisting sugar to preserve health), but moral selfcontrol (resisting impulses to refrain from cheating). 
This allows explaining another part of the puritanical constellation-the condemnation of immodesty. Behaviors condemned as immodest by puritanical standards typically involve emission of stimuli likely perceived as triggering impulses, thus favoring harmful self-control failures. Immodest clothing reveals cues of female fertility or sexual interest, such as body curves, skin, hair, or eyes (Pazhoohi, 2016; Pazhoohi \& Hosseinchari, 2014). Exposure to these cues is known to alter males' state-self-control, by triggering their reward systems and sexual appetite (Platek \& Singh, 2010; Spicer \& Platek, 2010; Symons, 1995), and increasing their preference for immediate over delayed rewards (Kim \& Zauberman, 2013; Wilson \& Daly, 2004). Studies also suggest that exposure to sexual cues increases males' propensity to engage in manipulative and coercive behaviors to obtain sexual gratification-and thus to facilitate, not only self-control failures in general, but also moral self-control failures (Ariely \& Loewenstein, 2006).

Prescriptions of modesty, we thus argue, are another strategy—besides prohibition of intoxicants-for preventing self-control failures with socially harmful effects. Immodest clothing and behaviors are moralized because, by increasing cue exposure, they are seen as increasing the probability that people_-especially males—lose control over impulses, thereby favoring antisocial behaviors such as sexual aggression, conflicts, adultery, or premarital sex ${ }^{3}$. Just as people remove tempting snacks from their environment when feeling unable to resist them, societies can deem mutually beneficial, when fearing the fragility of their members' self-control (see Section 5), to remove tempting stimuli from their environment to prevent uncooperative behaviors.

This hypothesis contrasts with existing accounts of modesty norms, which mainly regard them as selfish attempts of males to guard their mates (Dickemann, 1981; Pazhoohi et al., 2017). While

\footnotetext{
3 Premarital sex also amounts to cheating other people in some social contexts. In many societies, marriage is not only a cooperative interaction between spouses, but also a way to forge social exchange relationships between families (Coontz, 2006; Schlegel, 1991). In this context, young people's premarital sex incurs important costs to families, for example by decreasing daughters' "value" on the matrimonial market (Beckmann, 2010, p. 623; Dickemann, 1981; LeVine, 1959, pp. 978-979), or leading to costly pregnancies out of wedlock or unwanted marriages (Broude, 1996; Dabhoiwala, 2012b, pp. 29-30; Goody, 1976, p. 17). As a result, everyone may benefit if everyone limits premarital promiscuity, which, as a threat to the public good, is collectively condemned and brings a bad moral reputation to "fornicators" and their relatives (Beckmann, 2010, pp. 622-623; Dabhoiwala, 2012b, p. 618).
} 
males' mate-guarding interests likely contribute to these norms' attractiveness, we propose that moralization of modesty also emerge from more widely shared concern for the general social harm (e.g., conflicts, aggressions, infidelity) that may result from failures to control sexual impulses.

\subsubsection{Lay theories of modifiers of trait-self-control}

Other behaviors of the puritanical constellation, we argue, are perceived as altering self-control as a trait - that is, as the stable psychological disposition to resist temptations across situations. We term them "modifiers of trait-self-control."

Immoderate indulgence in bodily pleasures. Moralizations of victimless bodily pleasures, we argue, stem from perceptions that excessively or too frequently indulging in bodily pleasures would decrease trait-self-control. Such beliefs may be grounded in experience: the bodily pleasures typically condemned by puritanical standards generate common addictions, such as food addictions (Volkow et al., 2011, 2017), sexual addictions (Farré et al., 2015; Karila et al., 2014), alcohol addiction (Vengeliene et al., 2008), drug addiction (Baler \& Volkow, 2007), or gambling disorder (Farré et al., 2015)—addiction being widely viewed as a disruption of selfcontrol (Baler \& Volkow, 2007; Vonasch et al., 2017). Researchers have long noted the potent reinforcement learning associated with consumption of bodily pleasures or intoxicants: past experience with such a reward (e.g., energy-rich food) increases the motivational drive ("wanting") elicited by future exposure to it, making harder the future self-control of the associated impulse (e.g., food craving; Baler \& Volkow, 2007; Story et al., 2014; Volkow et al., 2017).

Accordingly, a widespread belief seems to be that the more one indulges in bodily pleasures, the more their temptations become hard to resist. A significant share of people believes that pornography (Grubbs et al., 2018; Grubbs et al., 2019), fatty and sugary foods (Ruddock \& Hardman, 2017), and intoxicants (Edelstein et al., 2020; El Khoury et al., 2019) can be addictive, while experimental evidence suggests that people intuitively associate addiction with loss of selfcontrol (see Vonasch et al., 2017). In vignette studies, we found that participants judged individuals increasing their indulgence in bodily pleasures over several months (e.g., pornography, alcohol, fatty and sugary foods) as altering their trait-self-control as a result of this lifestyle change (Fitouchi, André, Baumard \& Nettle, 2022). Surveying religious attitudes toward 
pleasure, Glucklich (2020, pp. 13-27) concludes that the addictive character of food, sex, alcohol, or gambling, is a major concern across world religions. Reviewing attitudes toward sex in European history, Dabhoiwala (2012) highlights that "It was a Christian commonplace that anyone who succumbed to this impure appetite [lust], even just once, risked developing a fatal addiction to it" (p. 33). In Hinduism, similarly, "Ancient Indian texts often call the four major addictions that kings were vulnerable to 'the vices of lust', sometimes naming them after the activities themselves_-gambling, drinking, fornicating, hunting" (Doniger, 2014, p. 365). Table 1 summarizes selected cases of such folk-psychological beliefs in various cultural contexts.

Table 1. Examples of folk psychological beliefs about modifiers of trait-self-control

Folk-psychological beliefs

\section{Behaviors corrupting} dispositional self-control:

Excessive indulgence in bodily pleasures (e.g. sex, food, drinking) reinforces short-term cravings, leading to hard-to-control habits and addictions

\section{Selected societies and traditions (with references)}

Amhara, Ethiopia (Levine, 1965, p. 223)

Early, Medieval and early modern Christianity (Dabhoiwala, 2012, p. 33; Spiegel, 2020)

Chinese Warring States period (Nylan, 2001)

France, 19 ${ }^{\text {th }}$ century (Guerrand, 1984, p. 302)

Greco-Roman Antiquity, ascetic wisdoms (e.g. Stoicism, Platonism, Pythagoreanism) (Gaca, 2003; Irvine, 2009, pp. 114-115)

Nordic and English-speaking "temperance cultures" (19) c.)

(Levine, 1993; Yeomans, 2011)

North India (Vatuk \& Vatuk, 1967)

Hinduism and Ancient India (Doniger, 2014, pp. 363-371)

Contemporary conservative Protestantism (Sherkat \& Ellison, 1997)

Victorian England, 19th c. (Seidman, 1990, p. 50)

Zanzibar (Beckmann, 2010, p. 622)

Amhara (Reminick, 1975, p. 123)

Christian tradition (Spiegel, 2020a)

Chinese Confucian tradition (Csikszentmihalyi, 2009, 2020)

Greco-Roman ascetic spiritualities (Gaca, 2003)

Islamic tradition (el-Aswad, 2014; Garden, 2014; Rehman, 2019;

Schielke, 2009)

Japanese Buddhism (Mann, 2011)

Hinduism (Doniger, 2014)

Orissa, India (Menon, 2013)

Ona (Gusinde, 1931, p. 1470)

Tlingit (Kan, 1989, pp. 54-55, 59-60)

Ojibwa (Hallowell, 1976, pp. 96, 205, 418)

Tukano (Hugh-Jones, 1979, pp. 147, 271)

Enga (Wiessner \& Tumu, 1998, p. 218)

If people perceive that cooperation requires self-control (section 3.1.3.), and that overindulgence in bodily pleasures reduces self-control, they may moralize bodily pleasures as indirectly facilitating uncooperative behaviors. For example, if indulgence in sexual pleasure in victimless 
situations (e.g., masturbation, frequent sex within marriage), is perceived as making people addict to sex, it becomes responsible for impeding the control of sexual urges in cooperative situations as well, where these impulses are socially harmful (e.g., when resisting them is necessary to avoid adultery). If victimless gluttony is perceived as making people addict to food, it becomes responsible for fueling uncontrollable urges which, in other situations, will prove socially harmful (e.g., when resisting food cravings is necessary to respect others' property). Repeated indulgence in bodily pleasures may be perceived, more generally, as decreasing self-control across domains, thus decreasing people's cooperativeness in general. This would be consistent we the lay theory we discuss next: that repeatedly practicing self-control would train self-control.

Self-control training, daily self-discipline, and ritual observance. Another recurrent lay theory seems to be that self-control can be trained by repeated practice-although the objective efficacy of such training is scientifically debated (Berkman, 2016; Friese et al., 2017; Miles et al., 2016). Field experiments on parents suggest a widespread belief that children's self-control can be improved, associated with self-control-training practices, such as giving children unhealthy snacks less often, or bringing them less frequently to fast-food restaurants (Mukhopadhyay \& Yeung, 2010). In vignette studies, participants judged that sustained self-discipline over several months (e.g., exercising regularly, reducing indulgence in bodily pleasures) would likely improve a target's trait-self-control (Fitouchi et al., 2022). This is consistent with cross-culturally recurrent beliefs that investment in ascetic practices or effortful activities allow to "build character" and improve people's self-control (see Table 1).

If people perceive both that cooperation requires self-control (Righetti \& Finkenauer, 2011), and that regular self-discipline trains self-control, they may moralize effortful activities (e.g., waking up early, spiritual disciplines, needless hard-work), as means to "build character"-i.e., to improve the self-control required to honor prosocial obligations. This helps explaining another component of the puritanical constellation: the moralization of constant self-discipline, needless hard work, and unproductive effort, even when the latter are devoid of direct benefits to other people (Celniker et al., 2022; Tierney et al., 2021).

This also allows explaining the moralization of pious ritual observance. Indeed, psychologists have extensively argued that rituals of world religions, such as fasting, meditation, regular prayer, or effortful pilgrimages, appear specifically geared toward training self-control (Koole et al., 2017; McCullough \& Carter, 2013; McCullough \& Willoughby, 2009; Tian et al., 2018; Wood, 
2017; Geyer \& Baumeister, 2005). These rituals require sustained restrictions of bodily desires (e.g., fasting), commitment to regular practice (e.g., praying five times a day, at fixed hours), cognitive effort (e.g., reading and memorizing the scriptures), and repeated inhibition of spontaneous tendencies (McCullough \& Willoughby, 2009). We argue that these activities, as the rest of the puritanical constellation, are ascribed a moral disciplining function: cultivating the self-control perceived necessary to honor prosocial obligations. This allows explaining why moralizations of diligent ritual observance cluster with other puritanical values (section 1.1.)—so that "piety" is commonly listed, alongside temperance and restraint from bodily pleasures, among the core virtues of the "purity" morality (Graham et al., 2013; Haidt, 2012; Haidt \& Joseph, 2007).

\subsection{Puritanism and the moral mind}

Our last assumptions concern the cognitive mechanisms of moral judgement. First, our account rests on a unitary model to moral cognition, according to which moral judgements-including puritanical ones - are produced by a single, functionally unified cognitive system sensitive to cooperation. In line with other unitary theories of moral cognition (Gray et al., 2012, 2014; Schein \& Gray, 2015, 2018), we insist that the plurality of moral values at the cultural level does not imply the existence of a plurality of moral systems at the cognitive level. The same moral system can produce, based on the very same computational procedures, a wide variety of outputs, and thus culturally variable values, depending on the varying inputs that it receives (Aarøe \& Petersen, 2014; Nettle \& Saxe, 2020, 2021). In the case of puritanical norms, a domaingeneral system sensitive to harm (Gray et al., 2014), or fairness (Baumard et al., 2013), can moralize victimless behaviors, as long as it is fed by causal representations depicting those behaviors as indirectly leading to socially harmful outcomes.

Second, we assume that this moral system is triggered not only by intrinsic instances of uncooperative behaviors (e.g., violence, adultery, unfair sharing), but also by behaviors perceived as indirectly and probabilistically leading to social harm. This is consistent with experimental evidence that the triggering of moral judgement depends on the computation of a-potentially indirect—causal chain between a perpetrator's action and an undeserved cost imposed on another individual (Cushman, 2008; Guglielmo \& Malle, 2017; Sloman et al., 2009). Victimless excesses should be preemptively moralized when perceived to causally contribute, through their deleterious effects on self-control, to an increased prevalence of uncooperative behaviors. 
Restrained behaviors should be praised when perceived to positively contribute, through their preserving effects on self-control, to the improvement of people's cooperativeness.

\subsection{The cultural evolution of puritanism as a behavioral technology}

So far, we have focused on the psychological level of moral judgement. Yet puritanism also manifests in socially transmitted traits, subject to cultural elaboration. Carnal sins are not only judged in everyday life; they have been systematized in explicit religious classifications (e.g., the Seven deadly sins; Hill, 2011; Tentler, 2015). Ascetic rituals of fasting, meditation, or regular prayer have been crafted and institutionalized by doctrinal religions (Brown, 2012; Tentler, 2015). Legal regulations of alcohol have been gradually elaborated and negotiated in cultural groups (Martin, 2009; Matthee, 2014). Thus, the emergence of puritanical norms is also fruitfully conceived in cultural evolutionary terms. These puritanical cultural traits, we argue, have evolved as people, based on their folk-psychological theories of self-control, have attempted to facilitate self-control to ensure cooperative behavior.

Prominent cultural evolutionary theories argue that normative cultural traits, such as monogamous marriage (Henrich et al., 2012), moralizing religions (Norenzayan et al., 2016), or large-scale cooperative institutions (Richerson et al., 2016), spread in human populations because they procure objective adaptive benefits by increasing cooperation. While human enforcement mechanisms (e.g., reputation, punishment) can stabilize any norm (Aumann \& Shapley, 1994; Boyd \& Richerson, 1992), inter-group competition would favor cooperation-facilitating norms at the expense of other evolutionarily stable equilibria (Henrich \& Muthukrishna, 2021). Thus, one possibility is that puritanical norms emerge through random variation, as one of the many stable equilibria that enforcement mechanisms can maintain, and are then favored by cultural group selection. In this perspective, puritanical norms should be objectively effective in increasing cooperation by facilitating self-control (see McCullough \& Carter, 2013), and would be favored by impersonal selective pressures that are independent of people's understanding of the mechanisms these norms involve or the function they serve (see Henrich, 2017, 2020)

Another possibility, however, is that the cultural evolution of norms is driven by people's subjective perceptions that some norms are efficient in satisfying their goals, leading them to selectively retain these norms at the expense of others (Singh, 2022; Singh et al., 2017). This "subjective selection" approach stresses that providing objective benefits to individuals or groups is not necessary for many cultural traits to evolve (Singh, 2022). People use their 
intuitions and folk-theories to craft cultural traits. Sometimes, these intuitions accurately perceive objective benefits, leading people to retain adaptive technologies, such as efficient tools or weapons (Osiurak \& Reynaud, 2019). Other times, people's psychological biases and folktheories are simply erroneous, leading them to retain ineffective practices-such as divination (Hong \& Henrich, 2021), dark magic (Singh, 2021), bloodletting (Miton et al., 2015), shamanism (Singh, 2018), or rain-making rituals (Hong et al., 2022). Such technologies recurrently evolve in human societies despite providing no adaptive benefits, simply because people wrongly perceive them as beneficial.

Normative culture, we argue, is no different. Just as people use their technical reasoning to craft technical artifacts, they use their folk-psychology to design "behavioral" technologies (e.g., norms, religions, institutions) aimed at influencing other individuals' behaviors. For example, Ostrom (1990) famously reviewed how people in many small-scale communities deliberately developed, often through years of trial-and-error, institutional rules they perceived as efficient in limiting free-riding. Researchers similarly argue that beliefs in punitive gods develop because people's folk-psychology perceives these beliefs_-potentially wrongly—as likely to motivate others to cooperate (Fitouchi \& Singh, 2022).

We argue that puritanical norms, from disciplinary rituals to Victorian anti-masturbation campaigns (Seidman, 1990), emerge from similar processes. They culturally evolve as people, based on their folk-theories of self-control, attempt to manipulate the psychological mechanics of temptation and self-control to promote prosocial behavior (Fitouchi et al., 2021c). This drives the cultural evolution of norms aimed at training self-control (e.g., techniques of self-discipline, prohibitions of alcohol) or nudging resistance to temptations (e.g., modest clothing), to favor social harmony and mutually beneficial interactions. Just as for other technologies, these norms may or may not be objectively effective in promoting self-control and thus cooperation-what matters is that people perceive that they are. In fact, there is only mixed evidence that self-controltraining (Friese et al., 2017; Miles et al., 2016) and religious observance (Marcus \& McCullough, 2020) can actually make people more self-controlled. Of course, this doesn't imply that puritanical norms never work. Econometric analyses suggest that some moral crusades against alcohol $\left(19^{\text {th }}\right.$ and $20^{\text {th }}$ c.) have successfully reduced drunkenness-driven violent crimes (Lowe, 2020). Field experiments in Iran suggest that conservative religious clothing actually decreases chances of male-female encounter (Pazhoohi \& Burriss, 2016). In our model, however, these 
objective benefits will affect cultural evolutionary dynamics only if they are reflected in people's subjective perceptions of efficacy, thus impacting people's adoption and promotion strategies.

\section{Explaining the core features of puritanism}

This section derives predictions from the Moral Disciplining Theory (MDT), contrast them with those of alternative accounts, reviews current evidence supporting them, and outlines avenues for further testing. MDT generates predictions for the moralizations of each behavior of the "puritanical constellation", which can be tested independently—on bodily pleasures and lack of self-discipline (4.1.), intoxicants (4.2.), piety and ritual observance (4.3.), and immodest clothing, music and dances (4.4.).

Several predictions apply to each behavior of the constellation. For each behavior, MDT predicts that (a) its moralization should be most robustly associated with the perception that it affects cooperation (e.g., cause social harm); (b) the more people perceive the behavior as affecting selfcontrol, the more they should moralize it; and (c) the perception that the behavior affects selfcontrol should mediate the perception that it affects cooperation. Reliably disconfirming these predictions for a given behavior would result in falsification of MDT's hypothesis for the moralization of this behavior. Predictions that are more specific to one particular behavior (e.g., immodesty) are further specified in the dedicated subsection (e.g., 4.4.).

\subsection{The praise of temperance and the condemnation of bodily pleasures}

\subsubsection{Moralizations of bodily pleasures should be most robustly associated with perceptions that they facilitate social harm}

As a cooperation-based theory of puritanism, MDT predicts that moralizations of victimless bodily pleasures, and lack of self-discipline, should be most robustly associated with the perception that they facilitate uncooperative behaviors and cause social harm. In line with this idea, Schein et al. (2016) show that moralizations of sexual indulgences (e.g., oral sex) are most strongly associated with perceptions that these behaviors are "dangerous" or "harmful." Associations between disgust (or disgust-sensitivity) and moralizations of sexual indulgences disappear when perceptions of harm are controlled for (Schein et al., 2016; see also Gray et al., 2014; Gray \& Schein, 2016). In the General Social Survey, support for legal restrictions of 
pornography is associated with the belief that "sexual material lead people to commit rape" (Sherkat \& Ellison, 1997). In two vignette studies $(N>1,100)$, we presented participants with a target led to increase their indulgence in bodily pleasures, such as gluttony and masturbation (Fitouchi, André, Baumard \& Nettle, 2022). Participants judged that, as a result of this lifestyle change, the target had likely become more prone to uncooperative behaviors, such as refusing to help a friend, free-riding on colleagues' work, and cheating his partner if he had the chance (Fitouchi, et al., 2022). The more participants perceived that bodily pleasures would decrease the target's cooperativeness, the more they morally condemned victimless indulgence in those pleasures (Fitouchi et al., 2022).

At a more general level, MDT predicts that moralizations of victimless excesses should relate to cooperation-based moral concerns. By contrast, Moral Foundations Theory (MFT) argues that moralizations of self-discipline are part of disgust-based concerns unrelated to cooperation. Thus, as per Moral Foundations Theory, condemnations of victimless excesses should relate more strongly to "purity" concerns_-putatively independent of cooperation-than to other moral concerns unambiguously related to cooperation (e.g., loyalty). Across four studies using the Moral Foundations Questionnaire ( $N>3000)$, participants' tendency to moralize victimless excesses (e.g., snacking on junk food, getting high on drugs, failing to exercise) is predicted not only by concerns for "purity" - which MFT assumes to be independent of cooperation—, but also, and to a similar extent, by moral concerns uncontroversially related to cooperation, such as Loyalty/Betrayal, and Authority/Respect (Mooijman et al. 2018). This suggests that selfdiscipline is moralized because it is seen as necessary to ensure within-group cooperation and social order.

These findings are consistent with historical evidence. Historians and social scientists have argued that puritanical moral campaigns of Early Modern Europe_-variously labelled “disciplinary revolutions” (Gorski, 1993, 2003), “social disciplining” (Oestreich, 1982), “civilizing offensives" (Eisner, 2014; Powell, 2013), or "reform of popular culture" (Burke, 1978)_ condemned undisciplined indulgence in bodily pleasures to "foster forms of socialization that would promote cooperation and harmony and result in a well-disciplined and well-ordered society" (Martin, 2009, p. 9; Burke, 1978; Eisner, 2014; McIntosh, 2002). Similarly, ancient ascetic spiritualities (e.g., Late Stoicism, Platonism, early Christianity, Pythagoreanism), prescribed an "overall habituation to temperance" with the explicit aim to prevent bodily appetites to fuel antisocial behaviors (Gaca, 2003). As Platonism contended, for example, 
sexual eros and the other two core appetites [eating and drinking], unless held in check by reason, are the origin of human-motivated social ills because they stimulate all vices from avarice to zealotry. If only we minded the necessary limits of sexual activity and ate and drank moderately, the society of peace and justice would be ours for the taking (Gaca, 2003, pp. 35-36).

\subsubsection{The more people perceive bodily pleasures as altering self-control, the more they should moralize bodily pleasures}

MDT posits that people perceive bodily pleasures as degrading cooperativeness because they perceive bodily pleasures as degrading self-control, for example because of their addictive character. Thus, the more people perceive victimless bodily pleasures as addictive, or as altering self-control more generally, the more they should moralize bodily pleasures. In line with this idea, studies consistently find that the moralization of pornography is associated with the perception that it is addictive for the self (Grubbs et al., 2015; Grubbs et al., 2018; Grubbs, Wilt, et al., 2018). The perception that pornography is addictive is also more prevalent among religious people (Droubay \& Butters, 2020), who are known to moralize pornography more strongly (Droubay et al., 2021; Grubbs et al., 2015). In vignette studies, the more participants perceive indulgence in gluttony, masturbation, and harmless laziness, as reducing an individual's selfcontrol, the more they morally condemn victimless indulgence in those pleasures (Fitouchi et al., 2022).

\subsubsection{The perception that bodily pleasures alter self-control should mediate the perception that they affect cooperation}

Experimental evidence suggests that the perceived effect of bodily pleasures on self-control mediates their perceived effect on cooperativeness. In the above-mentioned studies, the effect of indulgence (vs. restraint) on a target's perceived change in cooperativeness was $100 \%$ mediated by the perceived deleterious effect of indulgence (vs. restraint) on the target's self-control (Fitouchi et al., 2022). In other words, participants perceived indulgence in bodily pleasures, as opposed to restraint, as increasing an individual's propensity to uncooperative behaviors almost exactly to the extent that they perceived indulgence (vs. restraint) as altering this individual's selfcontrol. 
This converges with experimental evidence on the moralization of gluttony. People regularly indulging in fatty and sugary foods (e.g., hamburgers, donuts), compared to people with healthy diets, are seen not only as less moral and less trustworthy (Mankar et al., 2008; Merritt, 2013; Oakes et al., 2004; Steim \& Nemeroff, 1995), but also as less self-controlled (Gerrits et al., 2009; Merritt, 2013; Puhl \& Heuer, 2010; Steim \& Nemeroff, 1995). Experimental evidence indicates that these perceptions of lower self-control mediate the relationship between indulgent (vs. restrained) diet and perceived lower morality and trustworthiness (Fitouchi et al., 2022; Merritt, 2013; Steim \& Nemeroff, 1995)—-more so than other mediators such as a health-related concerns or a general halo effect (Steim \& Nemerrof, 1995).

These results converge with historical and ethnographic evidence that, in various cultural contexts, overindulgence in food or sex is condemned as causing uncooperative behaviors through the erosion of self-control. Scholars have argued that moral panics over masturbation in Victorian England emerged from the fear that excessive sexual activity "could, and probably would, lead to habits of indulgence in sensual pleasure and thus cause the erosion of selfcontrol” (Hunt, 1998, p. 589; Seidman, 1990). Masturbation, or too frequent marital sexuality, were denounced as

a vice which excites...the strongest and most uncontrollable propensities of animal nature [i.e., sexual impulses]: these are rendered more active by indulgence, while the power of restraint is lessened by it in a tenfold degree... Controlled by sensual urges the individual loses self-control and social purpose. This inevitably leads to self-destruction and to social chaos and decline (Seidman, 1990, pp. 50-52, emphases added).

In Muslim Zanzibar, “once tried out, sex is said to dominate a person's thoughts with everincreasing desire and to make it difficult to refrain from behavior that is classified as immoral, including disrespect of the elders or drug and alcohol abuse” (Beckmann, 2010, p. 622). In North India, excessive indulgence in sweets is perceived to develop an impulsive character trait, leading to commit antisocial behaviors, "like cheating, stealing and selling daughter" (Vatuk \& Vatuk, 1967, p. 111). As ethnographers report:

The problem of the chatora [the sweet addict] in Indian society seems to be perceived by our informants as a problem of loss of control over the senses by the sweet addict...Excessive indulgence in sweets has made the chatora incapable of resisting the temptations which continually beset a man from all directions... The weakness of the chatora is inexcusable...because it is evidence of his potential weakness against all the temptations of anti-social behavior. (Vatuk \& Vatuk, 1967, pp. 111-112, emphases added). 
In the Amhara peasants (Ethiopia), "there is also the fear that if one indulges in eating and drinking he may become uncontrollably hostile" (Levine, 1965, p. 223), because "eating and drinking to full satiation, and maintaining this state over time, makes one thankless, arrogant, unmindful of law and custom, and dangerously impulsive" (Reminick, 1975, p. 29). Surveys of moral attitudes toward food since European Antiquity conclude that " $[\mathrm{t}]$ he heart of the problem it seems is that food pleasure challenges self-control" (Coveney, 2006, p. xii; Hill, 2011). In medieval Christianity, excessive food pleasure—alongside other deadly sins_- "represent devilish temptations that challenge the Christian to develop and practice discretion and self-control" (Hill, 2011, p. 135). By weakening the will, gluttony "turns humans into dishonest animals, destined for hell" (Hill, 2007, p. 68). By seeking "delicious viands," a man can "do good to fewer others and cannot withhold himself so that he may help a poor man, or two, or more" (Hill, 2007, p. 68). As Doniger (2014) highlights, similar rationales for abstaining from meat recur in Hindu texts: "flesh heats the passions and is, therefore, dangerous for the ideal Hindu person, who is always in control of his emotions." (p. 415).

\subsection{The praise of sobriety and the moralization of intoxicants}

According to existing theories, intoxicants are moralized because they elicit disgust (Horberg et al., 2009), or because they favor sexual promiscuity, thereby infringing on the self-interest on monogamous individuals (Kurzban et al., 2010). By contrast, MDT predicts that:

(i) the moralization of intoxicants should be most robustly related to the perception that they cause uncooperative behaviors in general-including in the sexual domain (e.g., infidelity), but not exclusively;

(ii) because they threaten not just monogamous individuals' self-interest, but mutually beneficial cooperation more generally (e.g., social harmony), intoxicants should be moralized not only by monogamous strategists, but also by other individuals;

(iii) the moralizations of intoxicants should be associated with the perception that they decrease self-control, either as a state, due to their immediate psychoactive effects (section 3.2.1.), or as a trait, due to their addictive nature (section 3.2.2.);

(iv) the perception that intoxicants decrease self-control should mediate the perceived relationship between intoxicant use and uncooperative behaviors.

Future studies could test these predictions. Several lines of evidence, in the meantime, suggest their plausibility. 
First, survey data show that people across countries believe that intoxicants and aggression are causally linked (Critchlow, 1986; Leigh, 1987; Lindman \& Lang, 1994; Paglia \& Room, 1998). In the 1996 General Social Survey, 70.9\% of respondents view people addicted to alcohol as likely to do something violent to others, while this proportion reaches $87.3 \%$ for people addicted to drugs (Pescosolido et al., 1999) — a pattern found in various studies and countries (Yang et al., 2017). In a representative sample of the UK population, "fear of violence," and perceptions that they have a "bad character" — a notion related to trustworthiness (Goodwin, 2015) — are the best predictors of stigmatizing attitudes toward heroin-addicts, explaining respectively $23.5 \%$ and $12.4 \%$ of the variance (Mushtaq et al., 2015). By contrast, perceived risk of contagion-relevant to the disgust-hypothesis - explained only $0.9 \%$ of the variance (Mushtaq et al., 2015). In a sample of 1512 Uruguayan adults, the strongest predictor of opposition to the government's recent decision to legalize marijuana is the belief that this law will worsen public security (Cruz et al., 2018).

This converges with historical and ethnographic evidence that moral concerns over drinking revolve around the uncooperative behaviors it facilitates, such as adultery, conflicts, economic free-riding, or poor performance of family roles (Eisner, 2014; Martin, 2002, 2009; McIntosh, 2002; Room, 1984; Room, 1996). In a systematic study of more than 200 English and French primary sources (e.g., sermons) from 1300 to 1700, Warner (1997) shows that drinking was condemned as causing six main types of social harm, including domestic violence, public violence, disrespect of authorities, and resources loss (placing economic burdens on the community). Legal regulations of drinking in traditional Europe $\left(13^{\text {th }}-18^{\text {th }} \mathrm{c}\right.$.) are declared necessary because alcohol is "the root and foundation of many other enormous sins, such as bloodshed, stabbing, murder, swearing, fornification [sic], adultery, and such like” (Martin, 2009, p. 2), and results in "idleness, blasphemy, homicides and other damage and harm" (Martin, 2009, p. 30). Analyses of articles on marijuana published in American popular magazines between 1935 and 1940 — a period of moral concern over drug use — similarly find that $85 \%$ mentioned violence as one of its effects (Himmelstein, 1983).

Second, intoxicants appear perceived as causing uncooperative behaviors because of their effects on self-control. In survey responses, beliefs that alcohol causes "loss of self-control" and "disinhibition" is associated with the belief that alcohol favors "nasty" behaviors (e.g., fights, aggression) $(r=0.54)$ (Leigh, 1987). Presenting participants with 15 vignettes of a dating 
situation, Shively (2001) asked participants to rate a man's level of self-control and likelihood of sexual aggression. As the man was described as more inebriated, participants perceived him as less self-controlled and less able to stop himself from sexual aggression. In other studies, participants judged that a target led to increase his consumption of alcohol would become less self-controlled, more likely to commit uncooperative behaviors, and would worsen his moral character as a result of this lifestyle change (Fitouchi et al., 2022). Perceived change in the targets' self-control fully mediated the effect of alcohol indulgence (vs. restraint) on perceived change in cooperativeness; and mediated $71 \%$ of its effect on perceived change in moral character (Fitouchi et al., 2022).

This converges with historical and ethnographic evidence. Studies of especially acute moral crusades against drinking ("temperance movements", $19^{\text {th }}$ c.) conclude that "in any place where temperance movements developed - alcohol was defined as dangerous, as a problem, in terms of its perceived ability to destroy individual self-control" (Levine, 1993; see also Eisner, 2014; Yeomans, 2011). As Gusfield (1997) summarizes,

Dominating the temperance ethic through much of the nineteenth and early twentieth century was a belief in the sinfulness and degradation of drinking per se. Use of spirits, beer, and wine was inherently threatening to the self-control that marked the moral and potentially successful person. Use endangered reputation, social standing, and income, and inevitably brought chronic inebriety and all its attendant harms. (Gusfield, 1997, p. 213, emphases added)

Earlier in history, medieval and Early Modern moralists condemned alcohol for "extinguishing reason and dulling the mind", making it "the gateway to other sins" (Martin, 2009, p. 21; see also Adamson, 2004, p. 93). Similar attributions occur in Medieval Chinese Buddhism (Stercx, 2005, pp. 224, 228). The Muslim Hadith similarly describes alcohol as "that which befogs the mind" (Michalak \& Trocki, 2006, p. 529), making it the "source (literally 'mother') of all evils" (Powell, 2004, p. 97). Further suggesting that moralizations of drinking aim at preventing loss of selfcontrol, they often apply with varying intensity to different groups of people, as a function of their perceived likelihood to lose self-control. For example, the Konso agriculturalists (Ethiopia), who "know only too well what disruptive effects drunkenness can have on social relations", reserved the right to consume alcohol to old men only, "supposed to be milder in their passions than the young, and more self-controlled" (Hallpike, 2008, p. 219; see also traditional Middle East: Matthee, 2014, p. 104).

\subsection{The praise of piety and ritual observance}


MDT maintains that pious ritual observance is morally praised because it is perceived to cultivate self-control and thus cooperativeness (section 3.2.2). Future research could test whether ritual observance is more strongly moralized by people perceiving regular practice of a religious discipline, such as fasting, meditation, or regular prayer, as an efficient way to increase one's ability to resist temptations_-including uncooperative ones. Several lines of evidence suggest the plausibility of this idea.

First, across countries with Hindu, Buddhist, Christian, and secular majorities $(N>3,200)$, religious people are perceived as less likely to commit uncooperative behaviors than nonreligious people (Gervais et al., 2017; Gervais, 2013, 2014), and part of this effect may be due to religious people being perceived as regularly cultivating their self-control. Consistent with this possibility, experimental evidence indicates that religious people are perceived not only as more trustworthy, but also as more self-controlled (Moon et al., 2018), and that the perception that they are more self-controlled mediates the relationship between religiosity and greater perceived trustworthiness (Moon et al., 2018). Among religious people, those described as respecting rituals that require exercising self-control (e.g., abstaining from meat during Lent for Christians) are perceived as more trustworthy than religious people who do not, across religious affiliations (Hall et al., 2015; see also Singh \& Henrich, 2020). Surveys of both Javanese Muslim and Christian American participants also find that a substantial share of both samples report increasing and expressing self-control as a motivation for fasting (Tamney, 1980, 1986).

These results converge with the fact that puritanical traditions explicitly ascribe self-controltraining functions to ritual performance, with the specific aim of facilitating prosocial behavior. Specialists of Confucianism have long noted that "the function of rituals has been seen in China as a kind of block against or prevention of the influence of desires or selfish behavior" (Csikszentmihalyi, 2009, pp. 523-524). By cultivating self-discipline (Slingerland, 2014, pp. 7080), and "blocking the overflow of desires" (Csikszentmihalyi, 2020, p. 7), ritual propriety was explicitly meant to facilitate prosocial behavior (Csikszentmihalyi, 2004, 2009, 2020; Graziani, 2009; Slingerland, 2014). Similarly in the Christian tradition: "as a Christian virtue, self-control is a product of spiritual discipline, a trait for which the Christian much engage in 'strict training" (Spiegel, 2020, p. 1; see also Gaca, 2003; Gorski, 2003). Several ritual practices (e.g., fasting, mediation, self-denial) are "aimed cultivating self-mastery or strength of will", allowing to "get 
the victory over wickedness" or "train the soul to decline genuinely appealing immoral choices" (Spiegel, 2020, pp. 1-12).

In ethnographic studies in Bhubaneswar (India), Odia Hindu report that daily performance of prayers and ablutions "teaches one to exercise self-control and enable one to cultivate selfdiscipline" (Menon, 2013, p. 204)—qualities they also see as required for doing one's duties toward others (Menon, 2013, pp. 201, 204). In Muslim Zanzibar, it is similarly acknowledged that the moral character trait of self-control "need[s] constant work and become[s] easier with growing age and piety” (Beckmann, 2010, p. 120; Islam more generally: Rehman, 2019; Garden, 2014), while in the Amhara (Ethiopia), "[t]he rigorous schedule of fasting is believed to help contain one's passions which could lead to an uncontrollable situation and eventual violence" (Reminick, 1975, p. 29). In Japanese Buddhist culture, practicing an "austere mental and physical discipline that one pursues for decades", such as rituals or martial arts, is seen as allowing to "become a person of great discipline, character, and compassion", who is "of far greater service to her neighbors" (Mann, 2011, pp. 74-77).

The moral disciplining theory could further be tested by quantitatively investigating the crosscultural association between the moral praise of ritual observance and such ascriptions of moral disciplining functions to ritual performance.

\subsection{The condemnation of immodest clothing, music, and dances}

MDT proposes that, to prevent social harm, puritanical values do not only prescribe behaviors viewed as improving people's “inner" self-control (e.g., disciplinary rituals, restraint from bodily pleasures), but also use what psychologists call "preventive" or "situational" strategies for selfcontrol (Duckworth et al., 2016; Hofmann \& Kotabe, 2012). Such strategies aim at lowering the demand for self-control by preventing temptations to arise in the first place (Duckworth et al., 2016). This, we have argued, is what modesty norms do by limiting exposure to sexual cues (e.g., female body curves), perceived as triggering hard-to-control sex drives in impulsive males, potentially resulting in uncooperative behaviors (e.g., adultery, sexual aggression) (section 3.2.1.). This hypothesis generates the following predictions.

\subsubsection{The more people perceive male self-control as vulnerable to cue-exposure, the more they should moralize immodesty}


If immodesty is moralized as a risk factor for harmful self-control failures, it should be all the more condemned that people perceive surrounding males as unable to resist sexual urges in the face of cue-exposure. Indeed, if males are believed able to remain peaceful and self-controlled even when exposed to tempting cues, immodesty should lose its (perceived) potential to generate social harm, and should therefore not be condemned. In line with this prediction, Moon et al. (2021) show that the more people stereotype men as unable to control their sexual urges, the more they moralize female immodest clothing and other cue-exposing behaviors (e.g., public breastfeeding). This effect does not generalize to phenomena unrelated to cue-exposure, and holds after controlling for participants' reproductive strategy and other potential confounds (e.g., religiosity, conservatism, benevolent or hostile sexism). This suggests that, although inherently harmless, immodesty is moralized because of its perceived potential implications on male moral self-control (Moon et al., 2021).

\subsubsection{Modesty norms should be well designed to prevent cue-exposure specifically}

Second, modesty norms should specifically target behaviors increasing cue-exposure. This seems to be the case. Eye-tracking experiments show that Islamic clothing decreases visual access to female body curves (Pazhoohi, Macedo, et al., 2017), and accordingly decrease males' rating of female attractiveness (Mahmud \& Swami, 2009; Pazhoohi \& Hosseinchari, 2014; Sheen et al., 2018). Modest clothing across puritanical traditions specifically hide such sexually arousing stimuli (e.g., Puritans' austere clothing: Bremer, 2009; Islamic veiling: Mernissi, 2011; Jewish Tžnibut dress: Andrews, 2010; Hindu India: Stephens, 1972, p. 4; Ancient Christian veiling: Tariq, 2013). Psychological evidence indicates that immodesty is more negatively viewed in publicthat is, when its cue-exposing effects are amplified (Acker, 2009). The Quran also specifies that elderly women, deemed less attractive, can go unveiled (Mernissi, 2011), and studies of rural Muslim villages report that demands of modesty apply less strongly to elderly women (Antoun, 1968, p. 683; Belghiti, 1969).

Music and dance, similarly, are often condemned as exposing people to auditory and visual stimuli impeding self-control, thus making antisocial behaviors more likely. Islamic warning against the dangers of music insist on its self-control-impeding effects: "music as an activity is about exciting pleasures that make humans slaves to unruly passions" (Kiyimba, 2012, pp. $93-$ 94); and compare music's psychological effects to those of alcohol: “avoid singing for it decreases shame, increases desire... and verily it takes the place of wine and does what 
drunkenness does.” (Otterbeck \& Ackfeldt, 2012, p. 232). Christian oppositions to dancing often specifically targeted the "mixed" dancing of men and women, exposing people to sexual cues and "lascivious" bodily movements (Wagner, 1997). In early China, Confucius condemned the "immoral, seductive popular music of Zheng", which "was sung by mixed groups of men and women, and gave rise to sexual improprieties” (Slingerland, 2014, p. 76). In early modern Europe, "plays, songs and, above all, dances were condemned for awakening dangerous emotions and as incitement to fornication" (Burke, 1978, p. 212), while festivals were denounced as "occasions of violence" (Burke, 1978, p. 212). Tellingly, the very same entertainment-music- can become morally praised when it takes the form of a disciplined, effortful, and patient activity perceived as cultivating people's self-control rather than impeding it, thus facilitating prosociality. For example, while he condemned arousing popular music, Confucius prescribed classical musical performance, precisely because the latter "place[s] limits on appetitive desires" and thus "promote[s] unselfishness... and prepare[s] people to behave morally in different domains of their life" (Csikszentmihalyi, 2020, pp. 7,5).

\section{Explaining the fall of puritanism}

Although widespread, puritanical values are not ubiquitous. Their most systematically documented pattern of variation is their decline in particularly rich, WEIRD societies. In line cultural psychological studies (Atari et al., 2022; Haidt et al., 1993; Shweder et al., 1987), the World Value Surveys demonstrate that virtually all societies, when they are made richer by modern economic development, progressively abandon puritanical values (Inglehart, 2018; Inglehart \& Baker, 2000). The richest regions of the world (e.g., Western Europe, North America, Australia/New Zealand) show the lowest levels of puritanical values, while the poorest regions (e.g., Africa, Middle East, Communist Asia) exhibit the highest levels (Weeden \& Kurzban, 2013). Why does puritanism decline in particularly rich, WEIRD societies?

MDT maintains that people promote puritanical norms to ensure the self-control necessary for cooperative behavior. Puritanical norms, however, have a cost: they restrict people's enjoyment of highly gratifying pleasures, and impose effortful disciplinary activities. Thus, puritanical norms should be perceived as morally warranted only when they are worth this cost. This should especially be the case in environments where people's spontaneous self-control is perceived as insufficient to ensure social order and acceptable levels of cooperation-making puritanical norms, precisely aimed at supplementing this fragile self-control, appear necessary. In fact, historians and social scientists have stressed that puritans' zealous emphasis on maintaining 
constant self-control was tied to an "extraordinary fear of disorder and anarchy" (Walzer, 1963, p. 84), alimented by a pessimistic view of human nature as naturally weak-willed, driven by powerful impulses, and perpetually tempted by selfishness (Sherkat \& Ellison, 1997; Luttmer, 2000; Seidman, 1990; Walzer, 1963, 1982).

This reasoning closely parallels the logic of variations in authoritarian values (Nettle \& Saxe, 2021), which are associated with puritanical values (Atari et al., 2022; Harper \& Rhodes, 2021). Nettle \& Saxe (2021) present experimental and cross-national evidence that, in poorer environments, people are more supportive of authoritarian leaders because they expect other people to spontaneously behave less cooperatively. This lower trust in others leads people to view strong leaders, who monitor and punish cheating intransigently, as necessary to ensure acceptable levels of cooperation (Nettle \& Saxe, 2021). Just as monitoring and punishment by authoritarian leaders appears less necessary in particularly rich environments, where people view others as spontaneously cooperative (Nettle \& Saxe, 2021), we argue that puritanical norms, aimed at disciplining others for cooperation, become unnecessary when people see others as spontaneously self-controlled and trustworthy.

In line with this idea, the particularly rich environments in which puritanism declines lead to the development of more inherently self-controlled psychologies. People living in materially safer environments, compared to people living in poverty, are spontaneously more self-controlled (Dohmen et al., 2018; Pepper \& Nettle, 2017; Sheehy-Skeffington, 2020), invest more in extended prosociality (Holland et al., 2012; Lettinga et al., 2020; Nettle, 2015; Silva \& Mace, 2014; Zwirner \& Raihani, 2020), are less susceptible to impulsive defection or retaliation (McCullough et al., 2012), and have higher trust in others (Alesina \& La Ferrara, 2002; Guillou et al., 2021; Petersen \& Aarøe, 2015; Ortis-Opsina, 2017).

Material security and higher levels of self-control are also associated with lower spontaneous engagement in the very self-control-impeding behaviors that puritanical norms preemptively restrict. Richer individuals are less susceptible to heavy drinking (Huckle et al., 2010; Lewer et al., 2016), which in turn predicts less alcohol-related "undesirable" outcomes (e.g., physical fights, being away from work) (Huckle et al., 2010). Higher SES predicts lower reward-sensitivity and greater inhibition (Yaple \& Yu, 2020), which are associated with lower vulnerability to addiction problems and cue-exposure (Auger et al., 2010; Gullo et al., 2014; Osadchiy et al., 2019; Rømer Thomsen et al., 2018; Story et al., 2014; Volkow et al., 2017). Urges for temperance likely 
become useless when people are more moderate anyway, and less likely to develop hard-tocontrol addictions to bodily pleasures. Prohibitions of alcohol likely become superfluous when people are less susceptible to heavy drinking, and when drinking generates less social problems anyway than in poorer societies (e.g., Medieval Europe: Eisner, 2001, 2003, 2014; Martin, 2009). Prescriptions of religious techniques of self-discipline likely seem unnecessary when people perceive others as disciplined enough to honor their duties.

This hypothesis generates testable predictions: puritanical values should decline when surrounding individuals are perceived as particularly self-controlled and trustworthy. In line with this prediction, recent analyses of the World Value Survey $(N>200,000)$ show that, across more than 100 countries, individuals with puritanical values have lower trust in others-i.e., more belief that surrounding individuals are not spontaneously cooperative. As mentioned above, the more people perceive males as spontaneously sexually self-controlled, the less they support puritanical restrictions of immodesty (Moon et al., 2021). In the United States, Van Leeuwen et al., (2014) find that living in a State where many people have short-term-oriented "life-history strategies" (which relate to lower self-control: Pepper \& Nettle, 2017) predicts individual endorsement of purity values more strongly and robustly than any other predictor-including pathogen-prevalence, relevant to disgust-based accounts of purity, but also urbanization, education, social class, and cognitive ability. Similarly, more religious and conservative American states, which are more puritanical, have been found to exhibit the greatest levels of pornography use (Edelman, 2009; MacInnis \& Hodson, 2015; Whitehead \& Perry, 2018), while prevalence of pornography use in 20 Arab-Muslim countries $(N>15,000)$ has been found to be higher than in some less puritanical countries (e.g., Australia, Italy) (Eljawad et al., 2021). Recent studies find that people holding "binding moral foundations", which include purity values, tend to be less self-controlled than people holding liberal, less puritanical values (Silver \& Silver, 2019). The moral disciplining model allows making sense of these apparently paradoxical findings, previously seen as left unexplained (see Silver \& Silver, 2019; van Leeuwen et al., 2014): the need to moralize bodily pleasures and self-discipline is felt more strongly when people perceive, by observing others' behaviors or extrapolating from their own psychology, that surrounding individuals' ability to resist temptations is not guaranteed, and thus needs to be compensated by puritanical restrictions.

\section{Extending and discussing the disciplining account}

\subsection{Self-control and other moralizations}


In this section, we further illustrate the fecundity of the moral disciplining approach, by showing how it can explain other Purity-related moral judgments beyond those considered so far in this article.

\subsubsection{Hygiene norms}

Moral psychologists often define Purity as condemning not only bodily pleasures and undisciplined lifestyles, but also dirty and unclean behaviors (Graham et al., 2013; Gray et al., 2022; Kollareth et al., 2022). Moral prescriptions of hygiene may seem, in line with Moral Foundations Theory (Graham et al., 2013), straightforwardly related to disgust and pathogenavoidance. Yet recent evidence suggests the fecundity of the moral disciplining framework to explain even this part of Purity concerns. In almost 20,000 participants across 56 countries, the restrictiveness of hygiene norms (e.g., against spitting, for handwashing) is more strongly and robustly predicted by the valorization of self-control than by perceived pathogen threat and historical pathogen prevalence-whose effect on the main factor of hygiene norms disappears when self-control values are controlled for (Eriksson et al., 2021). This suggests that not only ascetic restraint, but also the conscientious observance of hygienic practices, may be moralized as an exercise of self-discipline.

\subsection{2. "Impure thoughts" and the moralization of mental intimacy}

Puritanical traditions can go as far as moralizing, not only victimless behaviors and private lifestyles, but also the very mental states individuals experience, such as the "impure" thoughts and desires they may entertain. In psychological experiments, Christians and Protestant participants judge some mental states (e.g., adulterous desire) to be as immoral as the behaviors that could follow them (Cohen, 2003; Cohen \& Rozin, 2001; Siev \& Cohen, 2007). Early Church fathers (e.g., Paul, Matthew) insisted that a man looking with desire at a woman already commits adultery "in his heart" (Gaca, 2003, pp. 152-153). From the $13^{\text {th }}$ c. onwards, Christians were obligated to confess not only their immoral actions but also their sinful thoughts (Tentler, 2015). In the Muslim tradition, the condemnation of zina (unlawful, non-marital sex), also extends to mental states such as looking at the body curves of a woman ("inina of the eye") or hearing an unrelated woman's voice ("zina of the ear") (Bouhdiba, 2012, pp. 38-39; see also Rabbinic Judaism: Hezser, 2018, pp. 15-16). 
The moral disciplining account helps explain this phenomenon as a special case of prevention of harmful self-control failures. Picturing oneself enjoying a reward, for example in adulterous or violent thoughts, may be perceived as triggering urges to consume this reward (e.g., sexual pleasure), making people more likely to succumb harmful temptations (e.g., adultery, assault). As written in the most popular Christian devotional book (The Imitation of Christ, $15^{\text {th }}$ c.), "first there comes into the mind an evil thought: next, a [vivid] picture: then delight, and urge to evil" (Tentler, 2015, p. 156). According to our account, although inherently harmless, mental states and desires are moralized when perceived as critically increasing the probability of harmful selfcontrol failures.

In line with this idea, the puritanical moralization of mental states is often associated with prescriptions of "intra-psychic" self-control techniques (see Duckworth et al., 2016), aimed at detecting the birth of impulses in one's consciousness to facilitate their self-control. For example, historians have noted that "[i] $t$ was characteristic of puritans to subject themselves to intense self-examination" (Bremer, 2009, p. 38). By meditating frequently, and recording his impulses in moral diaries (Bremer, 2009; Gorski, 1993, 2003), the individual "was to reflect on the sins he was especially prone to commit so that he might guard against those urges" (Bremer, 2009 , p. 55). In the Christian tradition more generally, meditation has been construed as a selfcontrol technique that "kills temptation at the root, by producing a mental 'soil' that will not sustain the development of illicit desires that lead to vice" (Spiegel, 2020, p. 12). Neo-Confucian traditions under China's Song, Yuan and Ming Dynasties $\left(10^{\text {th }}-17^{\text {th }}\right.$ centuries $)$ similarly adopted and adapted techniques of meditation used to "detect and undercut selfish inclinations and desires" (Tiwald, 2020). In line with these cases, psychological evidence suggests that the tendency to attribute to others the ability to internally control their mental states and impulses predicts the propensity to moralize mental states (Weiss et al., 2021).

\subsection{Outstanding questions}

Purity was originally introduced to moral psychology to raise awareness on the cross-cultural variation of morality: beyond the harm- and fairness-centered values of WEIRD societies, morality involves, in more traditional societies, temperance, chastity, and piety (Haidt, 2012; Haidt et al., 1993; Henrich et al., 2010; Shweder et al., 1987). This cross-cultural revolution in moral psychology was essential, and led to systematic documentation of the fall of puritanical values in modern societies (see Section 5; Atari et al., 2022; Haidt et al., 1993). This movement, we suggest, should go one step further. 
Indeed, not all traditional societies are puritanical. Available cross-cultural codes suggest that small-scale societies, somewhat similarly to WEIRD societies, exhibit less moral emphasis on sexual restraint and modesty than larger-scale, traditional societies with world religions (Jackson et al., 2020; Murdock, 1949; Stephens, 1972). Ethnographers have reported lax attitudes toward bodily pleasure in various small-scale societies (e.g., !Kung: Lee, 2013; Azande, Central Africa: Evans-Pritchard, 1973; Nivkh: Shternberg, 1933; Chuckchee, Northeast Asia: Broude, 1996; Trobriander, Papua New Guinea: Malinowski, 1929; Weiner, 1988; Intuit: Hoebel, 2009). Even in larger-scale traditional societies, puritanical values seem not to always have been so prevalent than in the societies mentioned by initial emphases on Purity (e.g. contemporary India, rural Brazil; Haidt, 2012; Haidt et al., 1993; Shweder et al., 1987). Puritanical values appear to have increased in Ancient Rome between the late Republic and the early Empire (Duby et al., 1994; Norena, 2007; Rousselle, 2013; Veyne, 1978; see also Gaca, 2003). In China, while bodily pleasures appear less restricted in Antiquity (Goldin, 2017; Hinsch, 1994; Wells \& Yao, 2015), starting with the Tang and continuing through the Song, the Yuan, the Ming and the Qing, selfdiscipline, bodily pleasures, asceticism are increasingly moralized (Benn, 2005; Sommer, 2000; Suiming, 1998; Wells \& Yao, 2015; Yü, 2021). In medieval Europe, historical work similarly documents an increasingly strict policing of lack of self-control, sexual misconducts, alcohol consumption, and lax religious observance, culminating in the moralistic religious movements of the Early Modern period (Burke, 1978; Ingram, 1990, 1996; Martin, 2009; McIntosh, 2002).

In other words, the focus on the WEIRD/non-WEIRD dichotomy (Henrich et al., 2010) may have obscured substantial variation in puritanical values among non-WEIRD societies themselves, potentially limiting our understanding of the cross-cultural variation that psychological theories must account for. Furthering our understanding of the psychological origins of puritanical values, and testing predictions of various theories, requires the field to move forward a systematic, quantitative documentation of the full spectrum of puritanical values' variations across human societies.

\section{Conclusion}

Many societies develop apparently unnecessarily austere norms, depriving people from the harmless pleasures of life. In face of the apparent disconnect of puritanical values from cooperation, the latter have either been ignored by cooperation-centered theories of morality, or been explained by mechanisms orthogonal to cooperative challenges, such as concerns for the 
purity of the soul, rooted in disgust intuitions. We have argued for a theoretical reintegration of puritanical morality in the otherwise theoretically grounded and empirically supported perspective of morality as cooperation. For deep evolutionary reasons, cooperation as a longterm strategy requires resisting impulses for immediate pleasures. To protect cooperative interactions from the threat of temptation, many societies develop preemptive moralizations aimed at facilitating moral self-control. This may explain why, aside from values of fairness, reciprocity, solidarity or loyalty, many societies develop hedonically restrictive standards of sobriety, asceticism, temperance, modesty, piety, and self-discipline.

\section{Acknowledgements}

We thank Daniel Nettle, Hugo Mercier, Manvir Singh, Amine Sijilmassi, and four anonymous reviewers for their very thoughtful feedback on previous versions of this manuscript.

\section{Funding statement}

This work was supported by the EUR FrontCog grant ANR-17-EURE-0017.

\section{Conflict of interest}

None

\section{References}

Aarøe, L., \& Petersen, M. B. (2014). Crowding Out Culture: Scandinavians and Americans Agree on Social Welfare in the Face of Deservingness Cues. The Journal of Politics, 76(3), 684-697. https://doi.org/10.1017/S002238161400019X

Abrams, S., Jackson, J. C., Vonasch, A., \& Gray, K. (2020). Moralization of Religiosity Explains Worldwide Trends in Religious Belief [Preprint]. PsyArXiv. https://doi.org/10.31234/osf.io/5a2db Abu-Lughod, L. (2016). Veiled sentiments honor and poetry in a Bedouin society. University of California Press. Acker, M. (2009). Breast is Best...But Not Everywhere: Ambivalent Sexism and Attitudes Toward Private and Public Breastfeeding. Sex Roles, 61(7), 476-490. https://doi.org/10.1007/s11199-009-9655-z

Adamson, M. W. (2004). Food in medieval times. Greenwood Press.

Alesina, A., \& La Ferrara, E. (2002). Who trusts others? Journal of Public Economics, 85(2), 207-234. https://doi.org/10.1016/S0047-2727(01)00084-6

Alexander, R. D. (1987). The biology of moral systems. A. de Gruyter.

Alós-Ferrer, C., \& Garagnani, M. (2020). The cognitive foundations of cooperation. Journal of Economic Behavior \& Organization, 175, 71-85. https://doi.org/10.1016/j.jebo.2020.04.019 
André, J.-B., Debove, S., Fitouchi, L., \& Baumard, N. (2022). Moral cognition as a Nash product maximizer: An evolutionary contractualist account of morality [Preprint]. PsyArXiv. https://doi.org/10.31234/osf.io/2hxgu

Andrews, C. (2010). Defining and Exploring Modesty in Jewish American Women. Journal of Religion and Health, 50, 818-834. https://doi.org/10.1007/s10943-010-9435-7

Andrighetto, G., Capraro, V., Guido, A., \& Szekely, A. (2020). Cooperation, Response Time, and Social Value Orientation: A Meta-Analysis [Preprint]. PsyArXiv. https://doi.org/10.31234/osf.io/cbakz

Antoun, R. T. (1968). On the Modesty of Women in Arab Muslim Villages: A Study in the Accommodation of Traditions. American Anthropologist, 70(4), 671-697. https://doi.org/10.1525/aa.1968.70.4.02a00010

Ariely, D., \& Loewenstein, G. (2006). The heat of the moment: The effect of sexual arousal on sexual decision making. Journal of Behavioral Decision Making, 19(2), 87-98. https://doi.org/10.1002/bdm.501

Armstrong, T., Wilbanks, D., Leong, D., \& Hsu, K. J. (2020). Is There a Measurement Crisis in Disgust Research? [Preprint]. PsyArXiv. https://doi.org/10.31234/osf.io/a8u5m

Atari, M., Haidt, J., Graham, J., Koleva, S., Stevens, S. T., \& Dehghani, M. (2022). Morality Beyond the WEIRD: How the Nomological Network of Morality Varies Across Cultures. PsyArXiv. https://doi.org/10.31234/osf.io/q6c9r

Auger, N., Lo, E., Cantinotti, M., \& O’Loughlin, J. (2010). Impulsivity and socio-economic status interact to increase the risk of gambling onset among youth. Addiction, 105(12), 2176-2183. https://doi.org/10.1111/j.1360-0443.2010.03100.x

Aumann, R. J., \& Shapley, L. S. (1994). Long-term competition-A game-theoretic analysis. In Essays in game theory (pp. 1-15). Springer.

Axelrod, R., \& Hamilton, W. D. (1981). The Evolution of cooperation.

Axelrod, R. M. (2006). The evolution of cooperation (rev. ed). Basic Books.

Baler, R., \& Volkow, N. (2007). Drug addiction: The neurobiology of disrupted self-control. Trends in Molecular Medicine, 12, 559-566. https://doi.org/10.1016/j.molmed.2006.10.005

Barclay, P. (2013). Strategies for cooperation in biological markets, especially for humans. Evolution and Human Behavior, 34(3), 164-175. https://doi.org/10.1016/j.evolhumbehav.2013.02.002

Barton-Crosby, J., \& Hirtenlehner, H. (2021). The Role of Morality and Self-Control in Conditioning the Criminogenic Effect of Provocation. A Partial Test of Situational Action Theory. Deviant Behavior, 42(10), 1273-1294. https://doi.org/10.1080/01639625.2020.1738645

Baumard, N. (2016). The origins of fairness: How evolution explains our moral nature. Oxford University Press.

Baumard, N., André, J.-B., \& Sperber, D. (2013). A mutualistic approach to morality: The evolution of fairness by partner choice. Behavioral and Brain Sciences, 36(01), 59-78. https://doi.org/10.1017/S0140525X11002202 
Baumard, N., \& Chevallier, C. (2015). The nature and dynamics of world religions: A life-history approach. Proceedings of the Royal Society B: Biological Sciences, 282(1818), 20151593. https://doi.org/10.1098/rspb.2015.1593

Beal, B. (2020). What Are the Irreducible Basic Elements of Morality? A Critique of the Debate Over Monism and Pluralism in Moral Psychology. Perspectives on Psychological Science, 15(2), 273-290. https://doi.org/10.1177/1745691619867106

Becker, A. (2019). On the Economic Origins of Restrictions on Women's Sexuality.

Beckmann, N. (2010). Pleasure and danger: Muslim views on sex and gender in Zanzibar. Culture, Health \& Sexuality, 12(6), 619-632. https://doi.org/10.1080/13691051003663713

Belghiti, M. (1969). Les relations féminines et le statut de la femme dans la famille rurale dans trois villages de la Tessaout. Études sociologiques sur le Maroc. Bulletin Économique et Social Du Maroc, 289-361.

Benn, J. A. (2005). Buddhism, alcohol, and tea in medieval China. In Of Tripod and Palate (pp. 213-236). Springer.

Berkman, E. T. (2016). Self-regulation training. In Handbook of self-regulation: Research, theory, and applications (pp. 440-457).

Blake, K. R., Fourati, M., \& Brooks, R. C. (2018). Who suppresses female sexuality? An examination of support for Islamic veiling in a secular Muslim democracy as a function of sex and offspring sex. Evolution and Human Behavior, 39(6), 632-638. https://doi.org/10.1016/j.evolhumbehav.2018.06.006

Bloom, P. (2004). Descartes' baby: How the science of child development explains what makes us human (pp. xv, 271). Basic Books.

Bloom, P. (2013). Just babies: The origins of good and evil. Crown Publishers/Random House.

Boehm, C. (2012). Moral origins: The evolution of virtue, altruism, and shame. Basic Books.

Boswell, R. G., \& Kober, H. (2016). Food cue reactivity and craving predict eating and weight gain: A meta-analytic review. Obesity Reviews, 17(2), 159-177. https://doi.org/10.1111/obr.12354

Bouhdiba, A. (2012). Sexuality in islam. Saqi Books.

Bouwmeester, S., Verkoeijen, P. P. J. L., Aczel, B., Barbosa, F., Bègue, L., Brañas-Garza, P., Chmura, T. G. H., Cornelissen, G., Døssing, F. S., Espín, A. M., Evans, A. M., Ferreira-Santos, F., Fiedler, S., Flegr, J., Ghaffari, M., Glöckner, A., Goeschl, T., Guo, L., Hauser, O. P., ... Wollbrant, C. E. (2017). Registered Replication Report: Rand, Greene, and Nowak (2012). Perspectives on Psychological Science, 12(3), 527-542. https://doi.org/10.1177/1745691617693624

Boyd, R., \& Richerson, P. J. (1992). Punishment allows the evolution of cooperation (or anything else) in sizable groups. Ethology and Sociobiology, 13(3), 171-195. https://doi.org/10.1016/01623095(92)90032-Y

Boyd, R., \& Richerson, P. J. (2001). Norms and bounded rationality. Bounded Rationality: The Adaptive Toolbox, 281-296. 
Boyer, P., \& Baumard, N. (2016). The Diversity of Religious Systems Across History. In The Oxford Handbook of Evolutionary Psychology and Religion. (Vol. 1, pp. 1-25). Oxford University Press. https://doi.org/10.1093/oxfordhb/9780199397747.001.0001

Brady, A., Baker, L. R., \& Miller, R. S. (2020). Look but don't touch?: Self-regulation determines whether noticing attractive alternatives increases infidelity. Journal of Family Psychology, 34(2), 135.

Bremer, F. J. (2009). Puritanism: A Very Short Introduction. Oxford University Press.

Brett, E. I., Leavens, E. L., Miller, M. B., Lombardi, N., \& Leffingwell, T. R. (2016). Normative perceptions of alcohol-related consequences among college students. Addictive Behaviors, 58, 16 20. https://doi.org/10.1016/j.addbeh.2016.02.008

Brokaw, C. J. (2014). The Ledgers of Merit and Demerit: Social Change and Moral Order in Late Imperial China. University Press.

Broude, G. J. (1996). Variations in sexual attitudes, norms and practices. Cross-Cultural Research for Social Sciences, 123-151.

Broude, G. J., \& Greene, S. J. (1976). Cross-Cultural Codes on Twenty Sexual Attitudes and Practices. Ethnology, 15(4), 409-429. JSTOR. https://doi.org/10.2307/3773308

Brown, P. (2012). The Rise of Western Christendom: Triumph and Diversity, A.D. 200-1000. John Wiley \& Sons.

Burke, P. (1978). Popular Culture in Early Modern Europe (Harper Torchbooks).

Burnette, J. L., Davisson, E. K., Finkel, E. J., Van Tongeren, D. R., Hui, C. M., \& Hoyle, R. H. (2014). Self-Control and Forgiveness: A Meta-Analytic Review. Social Psychological and Personality Science, 5(4), 443-450. https://doi.org/10.1177/1948550613502991

Buss, D. M., \& Schmitt, D. P. (1993). Sexual Strategies Theory: An evolutionary perspective on human mating. Psychological Review, 100(2), 204-232. https://doi.org/10.1037/0033-295X.100.2.204

Buyukcan-Tetik, A., Finkenauer, C., Siersema, M., Vander Heyden, K., \& Krabbendam, L. (2015). Social Relations Model Analyses of Perceived Self-Control and Trust in Families. Journal of Marriage and Family, 77(1), 209-223. https://doi.org/10.1111/jomf.12154

Buyukcan-Tetik, A., \& Pronk, T. (2021). Partner self-control and intrusive behaviors: A gender-specific examination of the mediating role of trust. Current Psychology, 3. https://doi.org/10.1007/s12144021-02462-4

Bynum, C. W. (2000). Holy feast and holy fast: The religious significance of food to medieval women (1. paperback print., [reprinted]). Univ. of California Press.

Camerer, C. F., Dreber, A., Holzmeister, F., Ho, T.-H., Huber, J., Johannesson, M., Kirchler, M., Nave, G., Nosek, B. A., Pfeiffer, T., Altmejd, A., Buttrick, N., Chan, T., Chen, Y., Forsell, E., Gampa, A., Heikensten, E., Hummer, L., Imai, T., ... Wu, H. (2018). Evaluating the replicability of social science experiments in Nature and Science between 2010 and 2015. Nature Human Behaviour, 2(9), 637-644. https://doi.org/10.1038/s41562-018-0399-z

Carlson, R. W., \& Crockett, M. J. (2018). The lateral prefrontal cortex and moral goal pursuit. Current Opinion in Psychology, 24, 77-82. https://doi.org/10.1016/j.copsyc.2018.09.007 
Carlson, S. M., \& Beck, D. M. (2001). Symbols as Tools in the Development of Executive Function. In A. Winsler, C. Fernyhough, \& I. Montero (Eds.), Private Speech, Executive Functioning, and the Development of Verbal Self-Regulation (pp. 163-175). Cambridge University Press. https://doi.org/10.1017/CBO9780511581533.014

Celniker, J. B., Gregory, A., Koo, H. J., Piff, P. K., Ditto, P. H., \& Shariff, A. F. (2022). The moralization of effort. Journal of Experimental Psychology: General.

Chakroff, A., Russell, P. S., Piazza, J., \& Young, L. (2017). From impure to harmful: Asymmetric expectations about immoral agents. Journal of Experimental Social Psychology, 69, 201-209. https://doi.org/10.1016/j.jesp.2016.08.001

Chapais, B. (2009). Primeval kinship: How pair-bonding gave birth to buman society. Harvard University Press.

Cheng, J. S., Ottati, V. C., \& Price, E. D. (2013). The arousal model of moral condemnation. Journal of Experimental Social Psychology, 49(6), 1012-1018. https://doi.org/10.1016/j.jesp.2013.06.006

Clark, C. A. (1932). Religions Of Old Korea. Fleming H. Revell Company. https://ehrafworldcultures-yaleedu.proxy.library.upenn.edu/document?id=aa01-005

Clifford, S., Iyengar, V., Cabeza, R., \& Sinnott-Armstrong, W. (2015). Moral foundations vignettes: A standardized stimulus database of scenarios based on moral foundations theory. Behavior Research Methods, 47(4), 1178-1198. https://doi.org/10.3758/s13428-014-0551-2

Cohen, A. B. (2003). Religion, Likelihood of Action, and the Morality of Mentality. International Journal for the Psychology of Religion, 13(4), 273-285. https://doi.org/10.1207/S15327582IJPR1304_4

Cohen, A. B., \& Rozin, P. (2001). Religion and the morality of mentality. Journal of Personality and Social Psychology, 81(4), 697-710. https://doi.org/10.1037/0022-3514.81.4.697

Cohen, T. R., Panter, A. T., Turan, N., Morse, L., \& Kim, Y. (2014). Moral character in the workplace. Joumal of Personality and Social Psychology, 107(5), 943.

Coontz, S. (2006). Marriage, a history: How love conquered marriage. Penguin.

Cosmides, L., Guzmán, R. A., \& Tooby, J. (2018). The evolution of moral cognition. Routledge.

Coveney, J. (2006). Food, morals and meaning: The pleasure and anxieties of eating. Routledge.

Craig, A. N., Peterson, Z. D., Janssen, E., Goodrich, M., David, \& Heiman, J. R. (2020). The Impact of Sexual Arousal and Emotion Regulation on Men's Sexual Aggression Proclivity. Journal of Interpersonal Violence, 0886260520915544. https://doi.org/10.1177/0886260520915544

Crawford, J. T., Inbar, Y., \& Maloney, V. (2014). Disgust sensitivity selectively predicts attitudes toward groups that threaten (or uphold) traditional sexual morality. Personality and Individual Differences, 70, 218-223. https://doi.org/10.1016/j.paid.2014.07.001

Critchlow, B. (1986). The Powers of John Barleycorn: Belies about the effects of alcohol on social behavior. American Psychologist, 14.

Crone, D. (2022). Conceptual issues with the moral foundation of Purity: The case of religion. PsyArXiv. https://doi.org/10.31234/osf.io/3e8bv 
Cruz, J. M., Boidi, M. F., \& Queirolo, R. (2018). Saying no to weed: Public opinion towards cannabis legalisation in Uruguay. Drugs: Education, Prevention and Policy, 25(1), 67-76. https://doi.org/10.1080/09687637.2016.1237475

Csikszentmihalyi, M. (2004). Material virtue: Ethics and the body in early China. Brill.

Csikszentmihalyi, M. (2009). Ethics And Self-Cultivation Practice In Early China. Early Chinese Religion, Part One: Shang through Han (1250 BC-220 AD) (2 Vols.), 519-542.

Csikszentmihalyi, M. (2020). Confucius. In E. N. Zalta (Ed.), The Stanford Encyclopedia of Philosophy

(Summer 2020). Metaphysics Research Lab, Stanford University.

https://plato.stanford.edu/archives/sum2020/entries/confucius/

Curry, O. S. (2016). Morality as Cooperation: A Problem-Centred Approach. In T. K. Shackelford \& R.

D. Hansen (Eds.), The Evolution of Morality (pp. 27-51). Springer International Publishing. https://doi.org/10.1007/978-3-319-19671-8_2

Curry, O. S., Jones Chesters, M., \& Van Lissa, C. J. (2019). Mapping morality with a compass: Testing the theory of 'morality-as-cooperation' with a new questionnaire. Journal of Research in Personality, 78 , 106-124. https://doi.org/10.1016/j.jrp.2018.10.008

Curry, O. S., Mullins, D. A., \& Whitehouse, H. (2019). Is It Good to Cooperate? Testing the Theory of Morality-as-Cooperation in 60 Societies. Current Antbropology, 60(1), 47-69. https://doi.org/10.1086/701478

Cushman, F. (2008). Crime and punishment: Distinguishing the roles of causal and intentional analyses in moral judgment. Cognition, 108(2), 353-380. https://doi.org/10.1016/j.cognition.2008.03.006

Dabhoiwala, F. (2012a). The origins of sex: A bistory of the first sexual revolution. Oxford University Press.

Dabhoiwala, F. (2012b). The Origins of Sex: A History of the First Sexual Revolution. Oxford University Press, USA.

de Ridder, D. T. D., Lensvelt-Mulders, G., Finkenauer, C., Stok, F. M., \& Baumeister, R. F. (2012). Taking Stock of Self-Control: A Meta-Analysis of How Trait Self-Control Relates to a Wide Range of Behaviors. Personality and Social Psychology Review, 16(1), 76-99. https://doi.org/10.1177/1088868311418749

Demos, K. E., Heatherton, T. F., \& Kelley, W. M. (2012). Individual Differences in Nucleus Accumbens Activity to Food and Sexual Images Predict Weight Gain and Sexual Behavior. Journal of Neuroscience, 32(16), 5549-5552. https://doi.org/10.1523/JNEUROSCI.5958-11.2012

DeScioli, P. (2016). The side-taking hypothesis for moral judgment. Current Opinion in Psychology, 7, 23-27. https://doi.org/10.1016/j.copsyc.2015.07.002

DeScioli, P., \& Kurzban, R. (2009). Mysteries of morality. Cognition, 112(2), 281-299. https://doi.org/10.1016/j.cognition.2009.05.008

DeScioli, P., \& Kurzban, R. (2013). A solution to the mysteries of morality. Psychological Bulletin, 139(2), 477-496. https://doi.org/10.1037/a0029065 
DeScioli, P., Massenkoff, M., Shaw, A., Petersen, M. B., \& Kurzban, R. (2014). Equity or equality? Moral judgments follow the money. Proceedings of the Royal Society B: Biological Sciences, 281(1797), 20142112. https://doi.org/10.1098/rspb.2014.2112

Dickemann. (1981). Paternal confidence and dowry competition: A biocultural analysis of purdah. In Natural selection and social behavior.

Dohmen, T., Enke, B., Falk, A., Huffman, D., \& Sunde, U. (2018). Patience and comparative development. University of Bonn. Mimeo.

Doniger, W. (2014). On Hinduism. Oxford University Press.

Droubay, B. A., \& Butters, R. P. (2020). Pornography, religiosity, and social work. Journal of Social Work, 20(5), 557-575. https://doi.org/10.1177/1468017319852599

Droubay, B., Butters, R., \& Shafer, K. (2021). The Pornography Debate: Religiosity and Support for Censorship. Journal of Religion and Health. https://doi.org/10.1007/s10943-018-0732-x

Duby, G., Pantel, P. S., Thébaud, F., \& Perrot, M. (1994). A History of Women in the West: Toward a Cultural Identity in the 20th Century. Belknap Press.

Duckworth, A. L., Gendler, T. S., \& Gross, J. J. (2016). Situational Strategies for Self-Control. Perspectives on Psychological Science, 11(1), 35-55. https://doi.org/10.1177/1745691615623247

Duckworth, A. L., \& Seligman, M. E. P. (2017). The Science and Practice of Self-Control. Perspectives on Psychological Science, 12(5), 715-718. https://doi.org/10.1177/1745691617690880

Duckworth, A. L., White, R. E., Matteucci, A. J., Shearer, A., \& Gross, J. J. (2016). A stitch in time: Strategic self-control in high school and college students. Journal of Educational Psychology, 108(3), 329-341. https://doi.org/10.1037/edu0000062

Duke, A. A., Smith, K. M. Z., Oberleitner, L. M. S., Westphal, A., \& McKee, S. A. (2018). Alcohol, drugs, and violence: A meta-meta-analysis. Psychology of Violence, 8(2), 238-249. https://doi.org/10.1037/vio0000106

Dungan, J., Chakroff, A., \& Young, L. (2017). The Relevance of Moral Norms in Distinct Relational Contexts: Purity versus harm norms regulate self-directed actions. PLoS ONE, 12, e0173405. https://doi.org/10.1371/journal.pone.0173405

Edelman, B. (2009). Markets: Red Light States: Who Buys Online Adult Entertainment? Journal of Economic Perspectives, 23(1), 209-220. https://doi.org/10.1257/jep.23.1.209

Edelstein, O. E., Wacht, O., Grinstein-Cohen, O., Reznik, A., Pruginin, I., \& Isralowitz, R. (2020). Does religiosity matter? University student attitudes and beliefs toward medical cannabis. Complementary Therapies in Medicine, 51, 102407. https://doi.org/10.1016/j.ctim.2020.102407

Eisner, M. (2001). Modernization, Self-Control and Lethal Violence. The Long-term Dynamics of European Homicide Rates in Theoretical Perspective. British Journal of Criminology, 41(4), 618-638. https://doi.org/10.1093/bjc/41.4.618

Eisner, M. (2003). Long-term historical trends in violent crime. Crime and Justice, 30, 83-142. 
Eisner, M. (2014a). From swords to words: Does macro-level change in self-control predict long-term variation in levels of homicide? Crime and Justice, 43(1), 65-134.

Eisner, M. (2014b). From Swords to Words: Does Macro-Level Change in Self-Control Predict Long-Term Variation in Levels of Homicide? 43, 65-134.

el-Aswad, E.-S. (2014). Patience in Sunni Muslim Worldviews. In D. A. Leeming (Ed.), Encyclopedia of Psychology and Religion (pp. 1318-1321). Springer US. https://doi.org/10.1007/978-1-4614-60862_9317

El Khoury, J., Noufi, P., Ahmad, A., Akl, E., \& El Hayek, S. (2019). Attitudes, beliefs, and knowledge of substance use amongst youth in the Eastern Mediterranean region: A systematic review. Drug and Alcohol Dependence, 196, 71-78. https://doi.org/10.1016/j.drugalcdep.2018.12.019

Eljawad, M. A., Se’eda, H., Ghozy, S., El-Qushayri, A. E., Elsherif, A., Elkassar, A. H., Atta-Allah, M. H., Ibrahim, W., Elmahdy, M. A., \& Islam, S. M. S. (2021). Pornography Use Prevalence and Associated Factors in Arab Countries: A Multinational Cross-Sectional Study of 15,027 Individuals. The Journal of Sexual Medicine. https://doi.org/10.1016/j.jsxm.2020.12.011

Ellis, L. (1988). The victimful-victimless crime distinction, and seven universal demographic correlates of victimful criminal behavior. Personality and Individual Differences, 9(3), 525-548. https://doi.org/10.1016/0191-8869(88)90151-1

Eriksson, K., Dickins, T. E., \& Strimling, P. (2021). Hygiene Norms Across 56 Nations are Predicted by Self-Control Values and Disease Threat. Current Research in Ecological and Social Psychology, 2, 100013. https://doi.org/10.1016/j.cresp.2021.100013

Evans-Pritchard, E. E. (1973). Some Notes on Zande Sex Habits. American Anthropologist, 75(1), 171-175. https://doi.org/10.1525/aa.1973.75.1.02a00100

Fan, W., Ren, M., Zhang, W., Xiao, P., \& Zhong, Y. (2020). Higher Self-Control, Less Deception: The Effect of Self-Control on Deception Behaviors. Advances in Cognitive Psychology, 16(3), 228-241. https://doi.org/10.5709/acp-0299-3

Farré, J. M., Fernández-Aranda, F., Granero, R., Aragay, N., Mallorquí-Bague, N., Ferrer, V., More, A., Bouman, W. P., Arcelus, J., Savvidou, L. G., Penelo, E., Aymamí, M. N., Gómez-Peña, M., Gunnard, K., Romaguera, A., Menchón, J. M., Vallès, V., \& Jiménez-Murcia, S. (2015). Sex addiction and gambling disorder: Similarities and differences. Comprehensive Psychiatry, 56, 59-68. https://doi.org/10.1016/j.comppsych.2014.10.002

Fehr, E., \& Leibbrandt, A. (2011). A field study on cooperativeness and impatience in the Tragedy of the Commons. Journal of Public Economics, 95(9-10), 1144-1155. https://doi.org/10.1016/j.jpubeco.2011.05.013

Finn, R. (2009). Asceticism In The Graeco-Roman World. Cambridge University Press.

Fitouchi, L., André, J.-B., \& Baumard, N. (2021a). Are there really so many moral emotions? 23.

Fitouchi, L., André, J.-B., \& Baumard, N. (2021b). Are there really so many moral emotions? Carving morality at its functional joints. 
Fitouchi, L., André, J.-B., \& Baumard, N. (2021c). The intertwined cultural evolution of ascetic spiritualities and puritanical religions as technologies of self-discipline. Religion, Brain \& Bebavior, 1-9. https://doi.org/10.1080/2153599X.2021.1881607

Fitouchi, L., André, J.-B., Baumard, N., \& Nettle, D. (2022). Harmless bodily pleasures are moralized because they are perceived as reducing self-control and cooperativeness. PsyArXiv. https://doi.org/10.31234/osf.io/fzv43

Fitouchi, L., \& Singh, M. (2022). Supernatural punishment beliefs as cognitively compelling tools of social control. Current Opinion in Psychology, 44, 252-257.

Franchin, L., Geipel, J., Hadjichristidis, C., \& Surian, L. (2019). Many moral buttons or just one? Evidence from emotional facial expressions. Cognition and Emotion, 33(5), 943-958. https://doi.org/10.1080/02699931.2018.1520078

Frank, R. H. (1988). Passions within reason: The strategic role of the emotions. W W Norton \& Co.

Friese, M., Frankenbach, J., Job, V., \& Loschelder, D. D. (2017). Does Self-Control Training Improve Self-Control? A Meta-Analysis. Perspectives on Psychological Science, 12(6), 1077-1099. https://doi.org/10.1177/1745691617697076

Fromell, H., Nosenzo, D., \& Owens, T. (2020). Altruism, fast and slow? Evidence from a meta-analysis and a new experiment. Experimental Economics, 23(4), 979-1001. https://doi.org/10.1007/s10683020-09645-z

Fujita, K. (2011). On Conceptualizing Self-Control as More Than the Effortful Inbibition of Impulses. 15(4), 352366.

Gaca, K. L. (2003). The Making of Fornication: Eros, Ethics, and Political Reform in Greek Philosophy and Early Christianity. University of California Press.

Gai, P. J., \& Bhattacharjee, A. (2022). Willpower as moral ability. Journal of Experimental Psychology: General. https://doi.org/10.1037/xge0001169

Gailliot, M. T., \& Baumeister, R. F. (2007). Self-Regulation and Sexual Restraint: Dispositionally and Temporarily Poor Self-Regulatory Abilities Contribute to Failures at Restraining Sexual Behavior. Personality and Social Psychology Bulletin, 33(2), 173-186. https://doi.org/10.1177/0146167206293472

Gan, G., Sterzer, P., Marxen, M., Zimmermann, U. S., \& Smolka, M. N. (2015). Neural and Behavioral Correlates of Alcohol-Induced Aggression Under Provocation. Neuropsychopharmacology, 40(13), 2886-2896. https://doi.org/10.1038/npp.2015.141

Gangestad, S. W., \& Simpson, J. A. (2000). The evolution of human mating: Trade-offs and strategic pluralism. Behavioral and Brain Sciences, 23(4), 573-587. https://doi.org/10.1017/S0140525X0000337X

Garden, K. (2014). The first Islamic reviver: Abü Hiamid al-Ghazää and his Revival of the religious sciences. Oxford University Press. 
Gay, J. L., David. (2000). Moral boundaries and deviant music: Public attitudes toward heavy metal and rap. Deviant Behavior, 21(1), 63-85. https://doi.org/10.1080/016396200266388

Gerrits, J. H., de Ridder, D. T. D., de Wit, J. B. F., \& Kuijer, R. G. (2009). Cool and independent or foolish and undisciplined? Adolescents' prototypes of (un)healthy eaters and their association with eating behaviour. Appetite, 53(3), 407-413. https://doi.org/10.1016/j.appet.2009.08.008

Gervais, W. M. (2013). In Godlessness We Distrust: Using Social Psychology to Solve the Puzzle of Antiatheist Prejudice: In Godlessness We Distrust. Social and Personality Psychology Compass, 7(6), 366377. https://doi.org/10.1111/spc3.12035

Gervais, W. M. (2014). Everything Is Permitted? People Intuitively Judge Immorality as Representative of Atheists. PLoS ONE, 9(4), e92302. https://doi.org/10.1371/journal.pone.0092302

Gervais, W. M., Xygalatas, D., McKay, R. T., van Elk, M., Buchtel, E. E., Aveyard, M., Schiavone, S. R., Dar-Nimrod, I., Svedholm-Häkkinen, A. M., Riekki, T., Klocová, E. K., Ramsay, J. E., \& Bulbulia, J. (2017). Global evidence of extreme intuitive moral prejudice against atheists. Nature Human Behaviour, 1(8), 0151. https://doi.org/10.1038/s41562-017-0151

Geyer, A. L., \& Baumeister, R. F. (2005). Religion, Morality, and Self-Control: Values, Virtues, and Vices. In Handbook of the psychology of religion and spirituality (pp. 412-432). The Guilford Press.

Ghelfi, E., Christopherson, C. D., Urry, H. L., Lenne, R. L., Legate, N., Fischer, M. A., Wagemans, F. M. A., Wiggins, B., Barrett, T., Bornstein, M., Haan, B. de, Guberman, J., Issa, N., Kim, J., Na, E., O’Brien, J., Paulk, A., Peck, T., Sashihara, M., ... Sullivan, D. (2020). Reexamining the Effect of Gustatory Disgust on Moral Judgment: A Multilab Direct Replication of Eskine, Kacinik, and Prinz (2011): Advances in Methods and Practices in Psychological Science. https://doi.org/10.1177/2515245919881152

Giancola, P. R., Josephs, R. A., Parrott, D. J., \& Duke, A. A. (2010). Alcohol Myopia Revisited: Clarifying Aggression and Other Acts of Disinhibition Through a Distorted Lens. Perspectives on Psychological Science, 5(3), 265-278. https://doi.org/10.1177/1745691610369467

Glucklich, A. (2020). The Joy of Religion: Exploring the Nature of Pleasure in Spiritual Life. Cambridge University Press.

Goldin, P. R. (2017). The Culture of Sex in Ancient China. University of Hawaii Press. https://doi.org/10.1515/9780824864651

Gomillion, S., Lamarche, V. M., Murray, S. L., \& Harris, B. (2014). Protected By Your Self-Control: The Influence of Partners' Self-Control on Actors' Responses to Interpersonal Risk. Social Psychological and Personality Science, 5(8), 873-882. https://doi.org/10.1177/1948550614538462

Goodman, C. (2017). Ethics in Indian and Tibetan Buddhism. In E. N. Zalta (Ed.), The Stanford Encyclopedia of Philosophy (Spring 2017). Metaphysics Research Lab, Stanford University. https://plato.stanford.edu/archives/spr2017/entries/ethics-indian-buddhism/

Goodwin, G. P. (2015). Moral Character in Person Perception. Current Directions in Psychological Science, 24(1), 38-44. https://doi.org/10.1177/0963721414550709 
Goodwin, G., Piazza, J., \& Rozin, P. (2013). Moral Character Predominates in Person Perception and Evaluation. Journal of Personality and Social Psychology, 106. https://doi.org/10.1037/a0034726

Goody, J. (1976). Production and reproduction: A comparative study of the domestic domain. Cambridge University Press.

Gorski, P. S. (1993). The Protestant Ethic Revisited: Disciplinary Revolution and State Formation in Holland and Prussia. American Journal of Sociology, 99(2), 265-316.

Gorski, P. S. (2003). The disciplinary revolution: Calvinism and the rise of the state in early modern Europe. University of Chicago Press.

Graham, J., Haidt, J., Koleva, S., Motyl, M., Iyer, R., Wojcik, S. P., \& Ditto, P. H. (2013a). Moral Foundations Theory. In Advances in Experimental Social Psychology (Vol. 47, pp. 55-130). Elsevier. https://doi.org/10.1016/B978-0-12-407236-7.00002-4

Graham, J., Haidt, J., Koleva, S., Motyl, M., Iyer, R., Wojcik, S. P., \& Ditto, P. H. (2013b). Moral foundations theory: The pragmatic validity of moral pluralism. In Advances in experimental social psychology (Vol. 47, pp. 55-130). Elsevier.

Graham, J., Haidt, J., \& Nosek, B. A. (2009). Liberals and conservatives rely on different sets of moral foundations. Journal of Personality and Social Psychology, 96(5), 1029-1046. https://doi.org/10.1037/a0015141

Gray, K., DiMaggio, N., Schein, C., \& Kachanoff, F. (2022). The Problem of Purity in Moral Psychology. Personality and Social Psychology Review.

Gray, K., \& Keeney, J. E. (2015). Impure or Just Weird? Scenario Sampling Bias Raises Questions About the Foundation of Morality. Social Psychological and Personality Science, 6(8), 859-868. https://doi.org/10.1177/1948550615592241

Gray, K., \& Schein, C. (2016). No Absolutism Here: Harm Predicts Moral Judgment 30× Better Than Disgust-Commentary on Scott, Inbar, \& Rozin (2016). Perspectives on Psychological Science, 11(3), 325-329. https://doi.org/10.1177/1745691616635598

Gray, K., Schein, C., \& Ward, A. F. (2014). The myth of harmless wrongs in moral cognition: Automatic dyadic completion from sin to suffering. Journal of Experimental Psychology: General, 143(4), 16001615. https://doi.org/10.1037/a0036149

Gray, K., Waytz, A., \& Young, L. (2012). The Moral Dyad: A Fundamental Template Unifying Moral Judgment. Psychological Inquiry, 23(2), 206-215. https://doi.org/10.1080/1047840X.2012.686247

Grubbs, J. B., Exline, J. J., Pargament, K. I., Hook, J. N., \& Carlisle, R. D. (2015). Transgression as Addiction: Religiosity and Moral Disapproval as Predictors of Perceived Addiction to Pornography. Archives of Sexual Behavior, 44(1), 125-136. https://doi.org/10.1007/s10508-013$0257-z$

Grubbs, J. B., Grant, J. T., \& Engelman, J. (2018). Self-identification as a pornography addict: Examining the roles of pornography use, religiousness, and moral incongruence. Sexual Addiction \& Compulsivity, 25(4), 269-292. https://doi.org/10.1080/10720162.2019.1565848 
Grubbs, J. B., Kraus, S. W., \& Perry, S. L. (2019). Self-reported addiction to pornography in a nationally representative sample: The roles of use habits, religiousness, and moral incongruence. Journal of Behavioral Addictions, 8(1), 88-93. https://doi.org/10.1556/2006.7.2018.134

Grubbs, J. B., Wilt, J. A., Exline, J. J., Pargament, K. I., \& Kraus, S. W. (2018). Moral disapproval and perceived addiction to internet pornography: A longitudinal examination. Addiction, 113(3), 496506. https://doi.org/10.1111/add.14007

Guerrand, R.-H. (1984). Haro sur la masturbation. In Amour et sexualité en Occident (pp. 99-102).

Guglielmo, S., \& Malle, B. F. (2017). Information-Acquisition Processes in Moral Judgments of Blame. Personality and Social Psychology Bulletin, 43(7), 957-971. https://doi.org/10.1177/0146167217702375

Guillou, L., Grandin, A., \& Chevallier, C. (n.d.). Temporal discounting mediates the relationship between socio-economic status and social trust. Royal Society Open Science, 8(6), 202104. https://doi.org/10.1098/rsos.202104

Gullo, M. J., Loxton, N. J., \& Dawe, S. (2014). Impulsivity: Four ways five factors are not basic to addiction. Addictive Behaviors, 39(11), 1547-1556.

Gurven, M., Winking, J., Kaplan, H., von Rueden, C., \& McAllister, L. (2009). A Bioeconomic Approach to Marriage and the Sexual Division of Labor. Human Nature, 20(2), 151-183. https://doi.org/10.1007/s12110-009-9062-8

Gusfield, J. R. (1997). The Culture of Public Problems: Drinking-Driving and the Symbolic Order. In Morality and Health. Routledge.

Gusinde, M. (1931). The Fireland Indians: Vol. 1. The Selk'Nam, On The Life And Thought Of A Hunting People Of The Great Island Of Tierra Del Fuego. Verlag der Internationalen Zeitschrift. https://ehrafworldcultures-yale-edu.proxy.library.upenn.edu/document?id=sh04-001

Hackett, C., \& McClendon, D. (2017). Christians remain world's largest religious group, but they are declining in Europe. Pew Research Center.

Haidt. (2012). The Righteous Mind: Why Good People Are Divided by Politics and Religion. Knopf Doubleday Publishing Group.

Haidt, J. (2007). The New Synthesis in Moral Psychology. Science, 316(5827), 998-1002. https://doi.org/10.1126/science.1137651

Haidt, J., \& Graham, J. (2007). When Morality Opposes Justice: Conservatives Have Moral Intuitions that Liberals may not Recognize. Social Justice Research, 20(1), 98-116. https://doi.org/10.1007/s11211-007-0034-z

Haidt, J., \& Hersh, M. A. (2001). Sexual morality: The cultures and emotions of conservatives and liberals. Journal of Applied Social Psychology, 31(1), 191-221.

Haidt, J., \& Joseph, C. (2004). Intuitive ethics: How innately prepared intuitions generate culturally variable virtues. Daedalus, 133(4), 55-66. 
Haidt, J., \& Joseph, C. (2007). The moral mind: How five sets of innate intuitions guide the development of many culture-specific virtues, and perhaps even modules. The Innate Mind, 3, 367-391.

Haidt, J., Koller, S. H., \& Dias, M. G. (1993). Affect, culture, and morality, or is it wrong to eat your dog? Journal of Personality and Social Psychology, 65(4), 613.

Hall, D. L., Cohen, A. B., Meyer, K. K., Varley, A. H., \& Brewer, G. A. (2015). Costly Signaling Increases Trust, Even Across Religious Affiliations. Psychological Science, 26(9), 1368-1376. https://doi.org/10.1177/0956797615576473

Hallowell, A. I. (Alfred I. (1976). Ojibwa World View And Disease. In Contributions To Anthropology: Selected Papers Of A. Irving Hallowell (pp. 391-448). University of Chicago Press. https://ehrafworldcultures-yale-edu.proxy.library.upenn.edu/document?id=ng06-077

Hallpike, C. (2008). The Konso of Ethiopia: A Study of the V alues of an East Cushitic People (Revised ed.). AuthorHouse.

Harper, C. A., \& Rhodes, D. (2021). Reanalysing the factor structure of the moral foundations questionnaire. British Journal of Social Psychology, 60(4), 1303-1329. https://doi.org/10.1111/bjso.12452

Harvey, P. (2000). An introduction to Buddhist etbics: Foundations, values and issues. Cambridge University Press.

Hatcher, B. A. (2017). India's many Puritans: Connectivity and friction in the study of modern Hinduism. History Compass, 15(1), e12369. https://doi.org/10.1111/hic3.12369

Heatherton, T. F., \& Wagner, D. D. (2011). Cognitive neuroscience of self-regulation failure. Trends in Cognitive Sciences, 15(3), 132-139. https://doi.org/10.1016/j.tics.2010.12.005

Hegland, M. E. (2004). Iranians. In C. R. Ember \& M. Ember (Eds.), Encyclopedia of Sex and Gender: Men and Women in the World's Cultures Volume I: Topics and Cultures A-K Volume II: Cultures L-Z (pp. 518529). Springer US. https://doi.org/10.1007/0-387-29907-6_52

Helzer, E. G., \& Pizarro, D. A. (2011). Dirty Liberals! Reminders of Physical Cleanliness Influence Moral and Political Attitudes. Psychological Science, 22(4), 517-522.

Henderson, N. L., \& Dressler, W. W. (2019). Cultural Models of Substance Misuse Risk and Moral Foundations: Cognitive Resources Underlying Stigma Attribution. Journal of Cognition and Culture, 19(1-2), 78-96. https://doi.org/10.1163/15685373-12340049

Henrich, J. (2017). The Secret of Our Success: How Culture Is Driving Human Evolution, Domesticating Our Species, and Making Us Smarter. Princeton University Press.

Henrich, J. (2020). The weirdest people in the world: How the west became psychologically peculiar and particularly prosperous. Farrar, Straus and Giroux.

Henrich, J., Boyd, R., \& Richerson, P. J. (2012). The puzzle of monogamous marriage. Philosophical Transactions of the Royal Society B: Biological Sciences, 367(1589), 657-669. https://doi.org/10.1098/rstb.2011.0290

Henrich, J., Heine, S. J., \& Norenzayan, A. (2010). The weirdest people in the world? Behavioral and Brain Sciences, 33(2-3), 61-83. https://doi.org/10.1017/S0140525X0999152X 
Henrich, J., \& Muthukrishna, M. (2021). The Origins and Psychology of Human Cooperation. Annual Review of Psychology, 72(1), 207-240. https://doi.org/10.1146/annurev-psych-081920-042106

Hershfield, H. E., Cohen, T. R., \& Thompson, L. (2012). Short horizons and tempting situations: Lack of continuity to our future selves leads to unethical decision making and behavior. Organizational Behavior and Human Decision Processes, 117(2), 298-310. https://doi.org/10.1016/j.obhdp.2011.11.002

Herz, R., \& Hinds, A. (2013). Stealing Is Not Gross: Language Distinguishes Visceral Disgust From Moral Violations. The American Journal of Psychology, 126, 275-286. https://doi.org/10.5406/amerjpsyc.126.3.0275

Hill, S. E. (2007). “The Ooze Of Gluttony”: Attitudes Towards Food, Eating, And Excess In The Middle Ages. The Seven Deadly Sins, 57-70.

Hill, S. E. (2011). Eating to excess: The meaning of gluttony and the fat body in the ancient world. Praeger.

Himmelstein, J. L. (1983). The strange career of maribuana: Politics and ideology of drug control in America (Vol. 94). Greenwood.

Hinsch, B. H. (1994). Women in early imperial China. Harvard University.

Hoebel, E. (2009). The law of primitive man: A study in comparative legal dynamics. Harvard University Press. Hofmann, W., \& Kotabe, H. (2012). A General Model of Preventive and Interventive Self-Control: PIModel of Self-Control. Social and Personality Psychology Compass, 6(10), 707-722. https://doi.org/10.1111/j.1751-9004.2012.00461.x

Hofmann, W., Meindl, P., Mooijman, M., \& Graham, J. (2018). Morality and self-control: How they are intertwined and where they differ. Current Directions in Psychological Science, 27(4), 286-291.

Hofmann, W., Wisneski, D. C., Brandt, M. J., \& Skitka, L. J. (2014). Morality in everyday life. Science, 345(6202), 1340-1343. https://doi.org/10.1126/science.1251560

Holland, J., Silva, A. S., \& Mace, R. (2012). Lost Letter Measure of Variation in Altruistic Behaviour in 20 Neighbourhoods. PLoS ONE, 7(8), e43294. https://doi.org/10.1371/journal.pone.0043294

Hong, Z., \& Henrich, J. (2021). The Cultural Evolution of Epistemic Practices: The Case of Divination. Human Nature, 32(3), 622-651. https://doi.org/10.1007/s12110-021-09408-6

Hong, Z., Slingerland, E., \& Henrich, J. (n.d.). Magic and empiricism in early Chinese rainmaking. Current Anthropology.

Horberg, E. J., Oveis, C., Keltner, D., \& Cohen, A. B. (2009). Disgust and the moralization of purity. Journal of Personality and Social Psychology, 97(6), 963-976. https://doi.org/10.1037/a0017423

Huckle, T., You, R. Q., \& Casswell, S. (2010). Socio-economic status predicts drinking patterns but not alcohol-related consequences independently. Addiction, 105(7), 1192-1202. https://doi.org/10.1111/j.1360-0443.2010.02931.x

Hugh-Jones, C. (1979). From The Milk River: Spatial And Temporal Processes In Northwest Amazonia. Cambridge University Press. https://ehrafworldcultures-yaleedu.proxy.library.upenn.edu/document?id=sq19-011 
Hunt, A. (1998). The great masturbation panic and the discourses of moral regulation in nineteenth-and early twentieth-century Britain. Journal of the History of Sexuality, 8(4), 575-615.

Hyman, S. E. (2007). The Neurobiology of Addiction: Implications for Voluntary Control of Behavior. The American Journal of Bioethics, 7(1), 8-11. https://doi.org/10.1080/15265160601063969

Inbar, Y., Pizarro, D. A., Knobe, J., \& Bloom, P. (2009). Disgust sensitivity predicts intuitive disapproval of gays. Emotion, 9(3), 435-439. https://doi.org/10.1037/a0015960

Inglehart, R. (2018). Cultural evolution: People's motivations are changing, and reshaping the world. Cambridge University Press.

Inglehart, R., \& Baker, W. E. (2000). Modernization, Cultural Change, and the Persistence of Traditional Values. American Sociological Review, 65(1), 19. https://doi.org/10.2307/2657288

Ingram, M. (1990). Church Courts, Sex and Marriage in England, 1570-1640. Cambridge University Press.

Ingram, M. (1996). Reformation of Manners in Early Modern England. In P. Griffiths, A. Fox, \& S. Hindle (Eds.), The Experience of Authority in Early Modern England (pp. 47-88). Macmillan Education UK. https://doi.org/10.1007/978-1-349-24834-6_3

Irvine, J. (1974). Caste And Communication In A Wolof Village. University Microfilms. https://ehrafworldcultures-yale-edu.proxy.library.upenn.edu/document?id=ms30-043

Irvine, W. B. (2009). A guide to the good life: The ancient art of Stoic joy. Oxford University Press.

Isler, O., Yilmaz, O., \& John Maule, A. (2021). Religion, parochialism and intuitive cooperation. Nature Human Behaviour, 5(4), 512-521. https://doi.org/10.1038/s41562-020-01014-3

Jackson, J. C., Gelfand, M., \& Ember, C. R. (2020). A global analysis of cultural tightness in non-industrial societies. Proceedings of the Royal Society B, 287(1930), 20201036.

Jacquet, P. O., Pazhoohi, F., Findling, C., Mell, H., Chevallier, C., \& Baumard, N. (2021). Predictive modeling of religiosity, prosociality, and moralizing in 295,000 individuals from European and non-European populations. Humanities and Social Sciences Communications, 8(1), 9. https://doi.org/10.1057/s41599-020-00691-9

Johnson, D. J., Wortman, J., Cheung, F., Hein, M., Lucas, R. E., Donnellan, M. B., Ebersole, C. R., \& Narr, R. K. (2016). The Effects of Disgust on Moral Judgments: Testing Moderators. Social Psychological and Personality Science, 7(7), 640-647. https://doi.org/10.1177/1948550616654211

Jylkkä, J., Härkönen, J., \& Hyönä, J. (2021). Incidental disgust does not cause moral condemnation of neutral actions. Cognition and Emotion, 35(1), 96-109. https://doi.org/10.1080/02699931.2020.1810639

Kammrath, L. K., \& Peetz, J. (2011). The limits of love: Predicting immediate versus sustained caring behaviors in close relationships. Journal of Experimental Social Psychology, 47(2), 411-417. https://doi.org/10.1016/j.jesp.2010.11.004

Kan, S. (1989). Symbolic Immortality: The Tlingit Potlatch Of The Nineteenth Century. Smithsonian Institution Press. https://ehrafworldcultures-yale-edu.proxy.library.upenn.edu/document?id=na12-032 
Karila, L., Wery, A., Weinstein, A., Cottencin, O., Petit, A., Reynaud, M., \& Billieux, J. (2014). Sexual Addiction or Hypersexual Disorder: Different Terms for the Same Problem? A Review of the Literature. Current Pharmacentical Design, 20(25), 4012-4020. https://doi.org/10.2174/13816128113199990619

Kayyal, M. H., Pochedly, J., McCarthy, A., \& Russell, J. A. (2015). On the limits of the relation of disgust to judgments of immorality. Frontiers in Psychology, 6. https://doi.org/10.3389/fpsyg.2015.00951

Keown, D. (2003). A dictionary of Buddhism. Oxford University Press.

Kim, B. K., \& Zauberman, G. (2013). Can Victoria’s Secret change the future? A subjective time perception account of sexual-cue effects on impatience. Journal of Experimental Psychology: General, 142(2), 328 .

Kiyimba, A. (2012). Music and Islam in Uganda: Diverse opinions and practices. Ethnomusicology in East Africa: Perspectives from Uganda and Beyond, 93-109.

Knoch, D., \& Fehr, E. (2007). Resisting the Power of Temptations: The Right Prefrontal Cortex and SelfControl. Annals of the New York. Academy of Sciences, 1104(1), 123-134. https://doi.org/10.1196/annals.1390.004

Knoch, D., Schneider, F., Schunk, D., Hohmann, M., \& Fehr, E. (2009). Disrupting the prefrontal cortex diminishes the human ability to build a good reputation. Proceedings of the National Academy of Sciences, 106(49), 20895-20899. https://doi.org/10.1073/pnas.0911619106

Kober, H., Mende-Siedlecki, P., Kross, E. F., Weber, J., Mischel, W., Hart, C. L., \& Ochsner, K. N. (2010). Prefrontal-striatal pathway underlies cognitive regulation of craving. Proceedings of the National Academy of Sciences, 107(33), 14811-14816. https://doi.org/10.1073/pnas.1007779107

Koleva, S. P., Graham, J., Iyer, R., Ditto, P. H., \& Haidt, J. (2012). Tracing the threads: How five moral concerns (especially Purity) help explain culture war attitudes. Journal of Research in Personality, 46(2), 184-194. https://doi.org/10.1016/j.jrp.2012.01.006

Kollareth, D., Brownell, H., Duran, J. I., \& Russell, J. A. (2022). Is purity a distinct and homogeneous domain in moral psychology? Journal of Experimental Psychology: General.

Kollareth, D., \& Russell, J. A. (2019). Disgust and the sacred: Do people react to violations of the sacred with the same emotion they react to something putrid? Emotion, 19(1), 37-52. https://doi.org/10.1037/emo0000412

Koole, S. L., Meijer, M., \& Remmers, C. (2017). Religious rituals as tools for adaptive self-regulation. Religion, Brain \& Behavior, 7(3), 250-253. https://doi.org/10.1080/2153599X.2016.1156562

Koval, C. Z., VanDellen, M. R., Fitzsimons, G. M., \& Ranby, K. W. (2015). The burden of responsibility: Interpersonal costs of high self-control. Journal of Personality and Social Psychology, 108(5), 750.

Kringelbach, M. L., \& Berridge, K. C. (2009). Towards a functional neuroanatomy of pleasure and happiness. Trends in Cognitive Sciences, 13(11), 479-487. https://doi.org/10.1016/j.tics.2009.08.006 
Kupfer, T. R., Inbar, Y., \& Tybur, J. M. (2020). Reexamining the role of intent in moral judgements of purity violations. Journal of Experimental Social Psychology, 91, 104043. https://doi.org/10.1016/j.jesp.2020.104043

Kurzban, R., Dukes, A., \& Weeden, J. (2010). Sex, drugs and moral goals: Reproductive strategies and views about recreational drugs. Proceedings of the Royal Society B: Biological Sciences, 277(1699), 35013508. https://doi.org/10.1098/rspb.2010.0608

Landy, J. F., \& Goodwin, G. P. (2015). Does Incidental Disgust Amplify Moral Judgment? A MetaAnalytic Review of Experimental Evidence. Perspectives on Psychological Science, 10(4), 518-536. https://doi.org/10.1177/1745691615583128

Landy, J., \& Piazza, J. (2017). Reevaluating Moral Disgust: Sensitivity to Many Affective States Predicts Extremity in Many Evaluative Judgments. Social Psychological and Personality Science, 10, 194855061773611. https://doi.org/10.1177/1948550617736110

Langlands, R. (2006). Sexual Morality in Ancient Rome. Cambridge University Press. https://doi.org/10.1017/CBO9780511482823

Le Goff, J. (1984). Le refus du plaisir in L'amour et la sexualité: Vol. Amour et Sexualité en Occident (Points Histoire, pp. 52-59).

Lee, R. B. (2013). The Dobe Ju/'hoansi (4th ed., Student ed). Wadsworth Cengage Learning.

Leigh, B. C. (1987a). Beliefs about the effects of alcohol on self and others. Journal of Studies on Alcohol, 48(5), 467-475. https://doi.org/10.15288/jsa.1987.48.467

Leigh, B. C. (1987b). Beliefs about the effects of alcohol on self and others. Journal of Studies on Alcohol, 48(5), 467-475. https://doi.org/10.15288/jsa.1987.48.467

Leimar, O., \& Connor, R. C. (2003). By-product benefits, reciprocity, and pseudoreciprocity in mutualism. Genetic and Cultural Evolution of Cooperation, 203-222.

Leimar, O., \& Hammerstein, P. (2010). Cooperation for direct fitness benefits. Philosophical Transactions of the Royal Society B: Biological Sciences, 365(1553), 2619-2626. https://doi.org/10.1098/rstb.2010.0116

Lettinga, N., Jacquet, P. O., André, J.-B., Baumand, N., \& Chevallier, C. (2020). Environmental adversity is associated with lower investment in collective actions. PLOS ONE, 15(7), e0236715. https://doi.org/10.1371/journal.pone.0236715

Levine, D. N. (1965). Wax \& Gold: Tradition And Innovation In Ethiopian Culture. University of Chicago Press. https://ehrafworldcultures-yale-edu.proxy.library.upenn.edu/document?id=mp05-011

Levine, H. (1993). Temperance Cultures: Concern About Alcohol as a Problem in Nordic and Englishspeaking Cultures. In The Nature of Alcohol and Drug-Related Problems (New York: Oxford University Press, pp. 16-36).

LeVine, R. A. (1959). Gusii Sex Offenses: A Study in Social Control. American Anthropologist, 61(6), 965990. https://doi.org/10.1525/aa.1959.61.6.02a00050 
Lewer, D., Meier, P., Beard, E., Boniface, S., \& Kaner, E. (2016). Unravelling the alcohol harm paradox: A population-based study of social gradients across very heavy drinking thresholds. BMC Public Health, 16, 1-11. https://doi.org/10.1186/s12889-016-3265-9

Lie-Panis, J., \& André, J.-B. (2022). Cooperation as a signal of time preferences. Proceedings of the Royal Society B: Biological Sciences, 289(1973), 20212266. https://doi.org/10.1098/rspb.2021.2266

Lindman, R. E., \& Lang, A. R. (1994). The Alcohol-Aggression Stereotype: A Cross-Cultural Comparison of Beliefs. International Journal of the Addictions, 29(1), 1-13. https://doi.org/10.3109/10826089409047365

Liu, H., \& Li, H. (2020). Self-Control Modulates the Behavioral Response of Interpersonal Forgiveness. Frontiers in Psychology, 11. https://doi.org/10.3389/fpsyg.2020.00472

Lowe, M. (2020). Religious Revival and Social Order.

Lugo, L., Cooperman, A., Bell, J., O’Connell, E., \& Stencel, S. (2013). The World's Muslims: Religion, Politics and Society. POLITICS AND SOCIETY, 226.

Luttmer, F. (2000). Persecutors, Tempters and Vassals of the Devil: The Unregenerate in Puritan Practical Divinity. The Journal of Ecclesiastical History, 51(1), 37-68. https://doi.org/10.1017/S0022046999002882

MacInnis, C. C., \& Hodson, G. (2015). Do American States with More Religious or Conservative Populations Search More for Sexual Content on Google? Archives of Sexual Behavior, 44(1), 137147. https://doi.org/10.1007/s10508-014-0361-8

Mahmud, Y., \& Swami, V. (2009). The influence of the hijab (Islamic head-cover) on perceptions of women's attractiveness and intelligence. Body Image, 7, 90-93. https://doi.org/10.1016/j.bodyim.2009.09.003

Malinowski, B. (1929). The sexual life of savages in northwestern Melanesia. [La vie sexuelle des sauvages $d u$ NordOuest de la Mélanesie. (Trans. By S. Jankelevitch.).]. Liveright.

Mankar, M., Joshi, R. S., Belsare, P. V., Jog, M. M., \& Watve, M. G. (2008). Obesity as a Perceived Social Signal. PLOS ONE, 3(9), 7.

Mann, J. K. (2011). Lutherans in Need of Self-Discipline: Japanese Shugyō and the Art of Sanctification. Dialog, 50(3), 271-279. https://doi.org/10.1111/j.1540-6385.2011.00620.x

Manrique, H. M., Zeidler, H., Roberts, G., Barclay, P., Walker, M., Samu, F., Fariña, A., Bshary, R., \& Raihani, N. (2021). The psychological foundations of reputation-based cooperation. Philosophical Transactions of the Royal Society B: Biological Sciences, 376(1838), 20200287. https://doi.org/10.1098/rstb.2020.0287

Marcus, Z. J., \& McCullough, M. E. (2020). Does Religion Make People More Self-Controlled? A Review of Research from The Lab and Life. Current Opinion in Psychology, S2352250X20302116. https://doi.org/10.1016/j.copsyc.2020.12.001

Martin, A. L. (2002). Alcohol, sex and gender in late medieval and early modern Europe. Palgrave.

Martin, A. L. (2009). Alcohol, violence, and disorder in traditional Europe. Truman State University Press. 
Matthee, R. (2014). Alcohol in the Islamic Middle East: Ambivalence and Ambiguity. Past \& Present, 222(suppl 9), 100-125. https://doi.org/10.1093/pastj/gtt031

Mcadams, D. P., Albaugh, M., Farber, E., Daniels, J., Logan, R. L., \& Olson, B. (2008). Family metaphors and moral intuitions: How conservatives and liberals narrate their lives. Journal of Personality and Social Psychology, 978-990.

McCullough, M. E., \& Carter, E. C. (2013). Religion, self-control, and self-regulation: How and why are they related? In APA bandbook of psychology, religion, and spirituality (Vol 1): Context, theory, and research (pp. 123-138). American Psychological Association. https://doi.org/10.1037/14045-006

McCullough, M. E., Pedersen, E. J., Schroder, J. M., Tabak, B. A., \& Carver, C. S. (2012). Harsh childhood environmental characteristics predict exploitation and retaliation in humans. Proceedings of the Royal Society B: Biological Sciences, 280(1750), 20122104-20122104. https://doi.org/10.1098/rspb.2012.2104

McCullough, M. E., \& Willoughby, B. L. B. (2009). Religion, self-regulation, and self-control: Associations, explanations, and implications. Psychological Bulletin, 135(1), 69-93. https://doi.org/10.1037/a0014213

McIntosh, M. K. (2002). Controlling Misbehavior in England, 1370-1600. Cambridge University Press.

McIntyre, J. C., Barlow, F. K., \& Hayward, L. E. (2015). Stronger sexual desires only predict bold romantic intentions and reported infidelity when self-control is low. Australian Journal of Psychology, 67(3), 178-186. https://doi.org/10.1111/ajpy.12073

Menon, U. (2013). The Hindu Concept of Self-refinement: Implicit yet Meaningful. Psychology and Developing Societies, 25(1), 195-222. https://doi.org/10.1177/0971333613477320

Mernissi, F. (2011). Beyond the Veil: Male-female Dynamics in Modern Muslim Society. Saqi Books.

Merritt, A. C. (2013). The Interpersonal Costs of Indulgence. Stanford University.

Michalak, L., \& Trocki, K. (2006). Alcohol and Islam: An Overview. Contemporary Drug Problems, 33(4), 523-562. https://doi.org/10.1177/009145090603300401

Miles, E., Sheeran, P., Baird, H., Macdonald, I., Webb, T. L., \& Harris, P. R. (2016). Does self-control improve with practice? Evidence from a six-week training program. Journal of Experimental Psychology: General, 145(8), 1075-1091. https://doi.org/10.1037/xge0000185

Milyavskaya, M., Saunders, B., \& Inzlicht, M. (2020). Self-control in daily life: Prevalence and effectiveness of diverse self-control strategies. Journal of Personality.

Mischel, H. N., \& Mischel, W. (1983). The Development of Children's Knowledge of Self-Control Strategies. 603619.

Miton, H., Claidière, N., \& Mercier, H. (2015). Universal cognitive mechanisms explain the cultural success of bloodletting. Evolution and Human Behavior, 36(4), 303-312. https://doi.org/10.1016/j.evolhumbehav.2015.01.003

Moffitt, T. E., Arseneault, L., Belsky, D., Dickson, N., Hancox, R. J., Harrington, H., Houts, R., Poulton, R., Roberts, B. W., Ross, S., Sears, M. R., Thomson, W. M., \& Caspi, A. (2011). A gradient of 
childhood self-control predicts health, wealth, and public safety. Proceedings of the National Academy of Sciences, 108(7), 2693-2698. https://doi.org/10.1073/pnas.1010076108

Mooijman, M., Meindl, P., Oyserman, D., Monterosso, J., Dehghani, M., Doris, J. M., \& Graham, J. (2018). Resisting temptation for the good of the group: Binding moral values and the moralization of self-control. Journal of Personality and Social Psychology, 115(3), 585-599. https://doi.org/10.1037/pspp0000149

Moon, J. W. (2021). Why are world religions so concerned with sexual behavior? Current Opinion in Psychology, 40, 15-19. https://doi.org/10.1016/j.copsyc.2020.07.030

Moon, J. W., Krems, J. A., \& Cohen, A. B. (2018). Religious People Are Trusted Because They Are Viewed as Slow Life-History Strategists. Psychological Science, 29(6), 947-960. https://doi.org/10.1177/0956797617753606

Moon, J. W., Krems, J. A., Cohen, A. B., \& Kenrick, D. T. (2019). Is Nothing Sacred? Religion, Sex, and Reproductive Strategies. Current Directions in Psychological Science, 28(4), 361-365. https://doi.org/10.1177/0963721419838242

Moon, J. W., Wongsomboon, V., \& Sevi, B. (2021). Beliefs about Men's Sexual Self-Control Predict Attitudes toward Women's Immodest Clotbing and Public Breastfeeding [Preprint]. PsyArXiv. https://doi.org/10.31234/osf.io/67vh9

Mukhopadhyay, A., \& Yeung, C. (2010). Building character: Effects of lay theories of self-control on the selection of products for children. 47(2), 240-250.

Murdock, G. P. (1949). Social structure (MacMillan).

Mushtaq, S., Mendes, V., Nikolaou, V., \& Luty, J. (2015). Analysis of the possible components of stigmatised attitudes towards depression and heroin dependence. Journal of Substance Use, 20(6), 399-406. https://doi.org/10.3109/14659891.2014.934306

Nabi, R. L. (2002). The theoretical versus the lay meaning of disgust: Implications for emotion research. Cognition \& Emotion, 16(5), 695-703. https://doi.org/10.1080/02699930143000437

Nag, M. (1972). Sex, Culture, and Human Fertility: India and the United States. Current Anthropology, 13(2), 231-237.

Najjar, L. Z., Young, C. M., Leasure, L., Henderson, C. E., \& Neighbors, C. (2016). Religious perceptions of alcohol consumption and drinking behaviours among religious and non-religious groups. Mental Health, Religion \& Culture, 19(9), 1028-1041.

Nemoto, T., Iwamoto, M., Morris, A., Yokota, F., \& Wada, K. (2007). Substance Use and Sexual Behaviors among Japanese Tourists, Students, and Temporary Workers in Honolulu, Hawaii. AIDS Education and Prevention, 19(1), 68-81. https://doi.org/10.1521/aeap.2007.19.1.68

Nettle, D. (2015). Tyneside neighbourboods: Deprivation, social life and social behaviour in one British city. Open Book Publishers. 
Nettle, D., \& Saxe, R. (2020). Preferences for redistribution are sensitive to perceived luck, social homogeneity, war and scarcity. Cognition, 198, 104234. https://doi.org/10.1016/j.cognition.2020.104234

Nettle, D., \& Saxe, R. (2021). 'If Men Were Angels, No Government Would Be Necessary': The Intuitive Theory of Social Motivation and Preference for Authoritarian Leaders. Collabra: Psychology, 7(1), 28105. https://doi.org/10.1525/collabra.28105

Nockur, L., \& Pfattheicher, S. (2021). The Beautiful Complexity of Human Prosociality: On the Interplay of Honesty-Humility, Intuition, and a Reward System. Social Psychological and Personality Science, 12(6), 877-886. https://doi.org/10.1177/1948550620961262

Norena, C. F. (2007). Hadrian's chastity. Phoenix, 296-317.

Norenzayan, A., Shariff, A. F., Gervais, W. M., Willard, A. K., McNamara, R. A., Slingerland, E., \& Henrich, J. (2016). The cultural evolution of prosocial religions. Behavioral and Brain Sciences, 39. https://doi.org/10.1017/S0140525X14001356

Nowak, M. A., \& Sigmund, K. (2005). Evolution of indirect reciprocity. Nature, 437(7063), 1291-1298. https://doi.org/10.1038/nature04131

NYLAN, M. (2001). On the Politics of Pleasure. Asia Major, 14(1), 73-124.

Oakes, M. E., Carole, \& Slotterback, S. (2004). Prejudgments of Those Who Eat a "Healthy" versus and "Unhealthy" Food for Breakfast. Curr Psychol, 267-278.

Oestreich, G., Oestreich, B., \& Koenigsberger, H. G. (1982). Neostoicism and the early modern state. Cambridge University Press.

Osadchiy, V., Mayer, E. A., Bhatt, R., Labus, J. S., Gao, L., Kilpatrick, L. A., Liu, C., Tillisch, K., Naliboff, B., Chang, L., \& Gupta, A. (2019). History of early life adversity is associated with increased food addiction and sex-specific alterations in reward network connectivity in obesity. Obesity Science \& Practice, 5(5), 416-436. https://doi.org/10.1002/osp4.362

Osiurak, F., \& Reynaud, E. (2019). The Elephant in the Room: What Matters Cognitively in Cumulative Technological Culture. Behavioral and Brain Sciences, 1-57. https://doi.org/10.1017/S0140525X19003236

Otterbeck, J., \& Ackfeldt, A. (2012). Music and Islam. Contemporary Islam, 6(3), 227-233. https://doi.org/10.1007/s11562-012-0220-0

Paglia, A., \& Room, R. (1998). Alcohol and aggression: General population views about causation and responsibility. Journal of Substance Abuse, 10(2), 199-216. https://doi.org/10.1016/S08993289(99)80134-5

Panchanathan, K., \& Boyd, R. (2004). Indirect reciprocity can stabilize cooperation without the secondorder free rider problem. Nature, 432(7016), 499-502. https://doi.org/10.1038/nature02978

Parrott, D. J., \& Eckhardt, C. I. (2018). Effects of alcohol on human aggression. Current Opinion in Psychology, 19, 1-5. https://doi.org/10.1016/j.copsyc.2017.03.023 
Partridge, C. H., \& Moberg, M. (Eds.). (2017). The Bloomsbury handbook of religion and popular music.

Bloomsbury Academic, an imprint of Bloomsbury Publishing Plc.

Pazhoohi, F. (2016). On the practice of cultural clothing practices that conceal the eyes: An evolutionary perspective. Evolution, Mind and Behaviour, 14. https://doi.org/10.1556/2050.2016.0002

Pazhoohi, F., \& Burriss, R. P. (2016). Hijab and "Hitchhiking": A Field Study. Evolutionary Psychological Science, 2(1), 32-37. https://doi.org/10.1007/s40806-015-0033-5

Pazhoohi, F., \& Hosseinchari, M. (2014). Effects of Religious Veiling on Muslim Men's Attractiveness Ratings of Muslim Women. Archives of Sexual Behavior, 43(6), 1083-1086. https://doi.org/10.1007/s10508-014-0259-5

Pazhoohi, F., Lang, M., Xygalatas, D., \& Grammer, K. (2017). Religious Veiling as a Mate-Guarding Strategy: Effects of Environmental Pressures on Cultural Practices. Evolutionary Psychological Science, 3(2), 118-124. https://doi.org/10.1007/s40806-016-0079-z

Pazhoohi, F., Macedo, A. F., \& Arantes, J. (2017). The Effect of Religious Clothing on Gaze Behavior: An Eye-Tracking Experiment. Basic and Applied Social Psychology, 39(3), 176-182. https://doi.org/10.1080/01973533.2017.1307748

Peake, P. K., Hebl, M., \& Mischel, W. (2002). Strategic attention deployment for delay of gratification in working and waiting situations. Developmental Psychology, 38(2), 313-326. https://doi.org/10.1037/0012-1649.38.2.313

Peetz, J., \& Kammrath, L. (2011). Only because I love you: Why people make and why they break promises in romantic relationships. Journal of Personality and Social Psychology, 100(5), 887-904. https://doi.org/10.1037/a0021857

Peetz, J., \& Kammrath, L. (2013). Folk understandings of self regulation in relationships: Recognizing the importance of self-regulatory ability for others, but not the self. Journal of Experimental Social Psychology, 49(4), 712-718. https://doi.org/10.1016/j.jesp.2013.02.007

Pepper, G. V., \& Nettle, D. (2017). The behavioural constellation of deprivation: Causes and consequences. Behavioral and Brain Sciences, 40. https://doi.org/10.1017/S0140525X1600234X

Pescosolido, B. A., Monahan, J., Link, B. G., Stueve, A., \& Kikuzawa, S. (1999). The public's view of the competence, dangerousness, and need for legal coercion of persons with mental health problems. American Journal of Public Health, 89(9), 1339-1345. https://doi.org/10.2105/AJPH.89.9.1339

Petersen, M. B. (2018). Reproductive interests and dimensions of political ideology. Evolution and Human Behavior, 39(2), 203-211. https://doi.org/10.1016/j.evolhumbehav.2017.12.002

Petersen, M. B., \& Aarøe, L. (2015). Birth Weight and Social Trust in Adulthood: Evidence for Early Calibration of Social Cognition. Psychological Science, 26(11), 1681-1692. https://doi.org/10.1177/0956797615595622

Piazza, J., Landy, J. F., Chakroff, A., Young, L., \& Wasserman, E. (2018). What disgust does and does not do for moral cognition. The Moral Psychology of Disgust, 53-81. 
Pizarro, D., Inbar, Y., \& Helion, C. (2011). On Disgust and Moral Judgment. Emotion Review, 3(3), 267268. https://doi.org/10.1177/1754073911402394

Platek, S., \& Singh, D. (2010). Optimal Waist-to-Hip Ratios in Women Activate Neural Reward Centers in Men. PloS One, 5, e9042. https://doi.org/10.1371/journal.pone.0009042

Poushter, J. (2014). What's morally acceptable? It depends on where in the world you live. Pew Research Center. https://www.pewresearch.org/fact-tank/2014/04/15/whats-morally-acceptable-itdepends-on-where-in-the-world-you-live/

Powell, A. (2004). Only in paradise: Alcohol and Islam. In Religion and Alcohol: Sobering Thoughts. (New York, Lang, pp. 95-110).

Powell, R. (2013). The Theoretical Concept of the 'Civilising Offensive' (Beschavingsoffensief): Notes on its Origins and Uses. Human Figurations, 2(2). http://hdl.handle.net/2027/spo.11217607.0002.203

Pronk, T. M., Karremans, J. C., \& Wigboldus, D. H. J. (2011). How can you resist? Executive control helps romantically involved individuals to stay faithful. Journal of Personality and Social Psychology, 100(5), 827-837. https://doi.org/10.1037/a0021993

Puhl, R. M., \& Heuer, C. A. (2010). Obesity Stigma: Important Considerations for Public Health. American Journal of Public Health, 100(6), 1019-1028. https://doi.org/10.2105/AJPH.2009.159491

Purzycki, B. G., Pisor, A. C., Apicella, C., Atkinson, Q., Cohen, E., Henrich, J., McElreath, R., McNamara, R. A., Norenzayan, A., Willard, A. K., \& Xygalatas, D. (2018). The cognitive and cultural foundations of moral behavior. Evolution and Human Behavior, 39(5), 490-501. https://doi.org/10.1016/j.evolhumbehav.2018.04.004

Quintelier, K. J. P., Ishii, K., Weeden, J., Kurzban, R., \& Braeckman, J. (2013). Individual Differences in Reproductive Strategy are Related to Views about Recreational Drug Use in Belgium, The Netherlands, and Japan. Human Nature, 24(2), 196-217. https://doi.org/10.1007/s12110-013$9165-0$

Rand, D. G. (2016). Cooperation, Fast and Slow: Meta-Analytic Evidence for a Theory of Social Heuristics and Self-Interested Deliberation. Psychological Science, 27(9), 1192-1206. https://doi.org/10.1177/0956797616654455

Rand, D. G. (2017). Social dilemma cooperation (unlike Dictator Game giving) is intuitive for men as well as women. Journal of Experimental Social Psychology, 73, 164-168. https://doi.org/10.1016/j.jesp.2017.06.013

Rand, D. G., Greene, J. D., \& Nowak, M. A. (2012). Spontaneous giving and calculated greed. Nature, 489(7416), 427-430. https://doi.org/10.1038/nature11467

Rand, D. G., \& Nowak, M. A. (2013). Human cooperation. Trends in Cognitive Sciences, 17(8), 413-425. https://doi.org/10.1016/j.tics.2013.06.003

Rehman, F. N. (2019). Self-Control in Islam and its Psychological Aspect. Journal of Religious Studies, 2(1), $16-36$. 
Reminick, R. A. (1975). The Structure And Functions Of Religious Belief Among The Amhara Of Ethiopia. In Proceedings Of The First United States Conference On Ethiopian Studies, Michigan State University, 2-5 May, 1973 (Issue 3, pp. 25-42). African Studies Center, Michigan State University. https://ehrafworldcultures-yale-edu.proxy.library.upenn.edu/document?id=mp05-022

Restubog, S. L. D., Garcia, P. R. J. M., Wang, L., \& Cheng, D. (2010). It's all about control: The role of self-control in buffering the effects of negative reciprocity beliefs and trait anger on workplace deviance. Journal of Research in Personality, 44(5), 655-660. https://doi.org/10.1016/j.jrp.2010.06.007

Richerson, P., Baldini, R., Bell, A. V., Demps, K., Frost, K., Hillis, V., Mathew, S., Newton, E. K., Naar, N., Newson, L., Ross, C., Smaldino, P. E., Waring, T. M., \& Zefferman, M. (2016). Cultural group selection plays an essential role in explaining human cooperation: A sketch of the evidence. Behavioral and Brain Sciences, 39. https://doi.org/10.1017/S0140525X1400106X

Righetti, F., \& Finkenauer, C. (2011). If you are able to control yourself, I will trust you: The role of perceived self-control in interpersonal trust. Journal of Personality and Social Psychology, 100(5), 874 886. https://doi.org/10.1037/a0021827

Ringel, M. M., \& Ditto, P. H. (2019). The moralization of obesity. Social Science \& Medicine, 237, 112399. https://doi.org/10.1016/j.socscimed.2019.112399

Ritter, R. S., Preston, J. L., Salomon, E., \& Relihan-Johnson, D. (2016). Imagine no religion: Heretical disgust, anger and the symbolic purity of mind. Cognition and Emotion, 30(4), 778-796. https://doi.org/10.1080/02699931.2015.1030334

Roberts, G. (2020). Honest signaling of cooperative intentions. Behavioral Ecology, 31(4), 922-932. https://doi.org/10.1093/beheco/araa035

Romain Graziani. (2009). Optimal States and Self-Defeating Plans: The Problem of Intentionality in Early Chinese Self-Cultivation. Philosophy East and West, 59(4), 440-466. https://doi.org/10.1353/pew.0.0067

Rømer Thomsen, K., Callesen, M. B., Hesse, M., Kvamme, T. L., Pedersen, M. M., Pedersen, M. U., \& Voon, V. (2018). Impulsivity traits and addiction-related behaviors in youth. Joumal of Behavioral Addictions, 7(2), 317-330. https://doi.org/10.1556/2006.7.2018.22

Room, R. (1996). Alcohol consumption and social harm-Conceptual issues and historical perspectives. Contemporary Drug Problems, 23(3), 373-388. https://doi.org/10.1177/009145099602300304

Room, R., Agar, M., Beckett, J., Bennett, L. A., Casswell, S., Heath, D. B., Leland, J., Levy, J. E., Madsen, W., Marshall, M., Moskalewicz, J., Negrete, J. C., Rodin, M. B., Sackett, L., Sargent, M., Strug, D., \& Waddell, J. O. (1984). Alcohol and Ethnography: A Case of Problem Deflation? [and Comments and Reply]. Current Anthropology, 25(2), 169-191. https://doi.org/10.1086/203107

Rousselle, A. (2013). Porneia: On Desire and the Body in Antiquity. Wipf and Stock Publishers. 
Royzman, E., Atanasov, P., Landy, J. F., Parks, A., \& Gepty, A. (2014). CAD or MAD? Anger (not disgust) as the predominant response to pathogen-free violations of the divinity code. Emotion, 14(5), 892-907. https://doi.org/10.1037/a0036829

Royzman, E. B., \& Sabini, J. (2001). Something it Takes to be an Emotion: The Interesting Case of Disgust. Journal for the Theory of Social Behaviour, 31(1), 29-59. https:// doi.org/10.1111/14685914.00145

Royzman, E., \& Kurzban, R. (2011). Minding the Metaphor: The Elusive Character of Moral Disgust. Emotion Review, 3(3), 269-271. https://doi.org/10.1177/1754073911402371

Rozin, P., \& Haidt, J. (2013). The domains of disgust and their origins: Contrasting biological and cultural evolutionary accounts. Trends in Cognitive Sciences, 17(8), 367-368.

Rozin, P., Haidt, J., \& McCauley, C. R. (2008). Disgust. In Handbook of emotions, 3rd ed (pp. 757-776). The Guilford Press.

Rozin, P., Lowery, L., Imada, S., \& Haidt, J. (1999). The CAD Triad Hypothesis: A Mapping Between Three Moral Emotions (Contempt. Disgust) and Three Moral Codes (Community, Autonomy, Divinity), Journal of Personality and Social Psychology 76/4.

Ruddock, H. K., \& Hardman, C. A. (2017). Food Addiction Beliefs Amongst the Lay Public: What Are the Consequences for Eating Behaviour? Current Addiction Reports, 4(2), 110-115. https://doi.org/10.1007/s40429-017-0136-0

Ruff, C. C., Ugazio, G., \& Fehr, E. (2013). Changing Social Norm Compliance with Noninvasive Brain Stimulation. Science, 342(6157), 482-484. https://doi.org/10.1126/science.1241399

Saroglou, V., \& Craninx, M. (2021). Religious moral righteousness over care: A review and a metaanalysis. Current Opinion in Psychology, 40, 79-85. https://doi.org/10.1016/j.copsyc.2020.09.002

Saroglou, V., Delpierre, V., \& Dernelle, R. (2004). Values and religiosity: A meta-analysis of studies using Schwartz's model. Personality and Individual Differences, 37(4), 721-734. https://doi.org/10.1016/j.paid.2003.10.005

Schein, C., \& Gray, K. (2015). The unifying moral dyad: Liberals and conservatives share the same harmbased moral template. Personality and Social Psychology Bulletin, 41(8), 1147-1163.

Schein, C., \& Gray, K. (2018). The Theory of Dyadic Morality: Reinventing Moral Judgment by Redefining Harm. Personality and Social Psychology Review, 22(1), 32-70. https://doi.org/10.1177/1088868317698288

Schein, C., Ritter, R. S., \& Gray, K. (2016). Harm mediates the disgust-immorality link. Emotion, 16(6), 862-876. https://doi.org/10.1037/emo0000167

Schielke, S. (2009). Being good in Ramadan: Ambivalence, fragmentation, and the moral self in the lives of young Egyptians. Journal of the Royal Anthropological Institute, 15, S24-S40.

Schlegel, A. (1991). Status, property, and the value on virginity. American Ethnologist, 18(4), 719-734. https://doi.org/10.1525/ae.1991.18.4.02a00050 
Schmitt, D. P. (2004). The Big Five related to risky sexual behaviour across 10 world regions: Differential personality associations of sexual promiscuity and relationship infidelity. European Journal of Personality, 18(4), 301-319. https://doi.org/10.1002/per.520

Sebastián-Enesco, C., \& Warneken, F. (2015). The shadow of the future: 5-Year-olds, but not 3-year-olds, adjust their sharing in anticipation of reciprocation. Joumal of Experimental Child Psychology, 129, 40-54. https://doi.org/10.1016/j.jecp.2014.08.007

Seidman, S. (1990). The Power of Desire and the Danger of Pleasure: Victorian Sexuality Reconsidered. Journal of Social History, 24(1), 47-67. https://doi.org/10.1353/jsh/24.1.47

Sheehy-Skeffington, J. (2020). The effects of low socioeconomic status on decision-making processes. Current Opinion in Psychology, 33, 183-188. https://doi.org/10.1016/j.copsyc.2019.07.043

Sheen, M., Yekani, H. A. K., \& Jordan, T. R. (2018). Investigating the effect of wearing the hijab: Perception of facial attractiveness by Emirati Muslim women living in their native Muslim country. PLOS ONE, 13(10), e0199537. https://doi.org/10.1371/journal.pone.0199537

Sherkat, D. E., \& Ellison, C. G. (1997). The Cognitive Structure of a Moral Crusade: Conservative Protestantism and Opposition to Pornography*. Social Forces, 75(3), 957-980. https://doi.org/10.1093/sf/75.3.957

Shively, M. (2001). Male self-control and sexual aggression. Deviant Behavior, 22(4), 295-321. https://doi.org/10.1080/016396201750267843

Shternberg, L. I. (1933). The Gilyak, Orochi, Goldi, Negidal, Ainu: Articles and materials. Human Relations Area Files.

Shweder, R. A., Mahapatra, M., \& Miller, J. G. (1987). Culture and moral development. In The emergence of morality in young children (pp. 1-83). University of Chicago Press.

Shweder, R. A., Much, N. C., Mahapatra, M., \& Park, L. (1997). The "big three" of morality (autonomy, community, divinity) and the "big three" explanations of suffering. In Morality and health (pp. 119-169). Taylor \& Frances/Routledge.

Siev, J., \& Cohen, A. B. (2007). Is thought-action fusion related to religiosity? Differences between Christians and Jews. Behaviour Research and Therapy, 45(4), 829-837. https://doi.org/10.1016/j.brat.2006.05.001

Silva, A. S., \& Mace, R. (2014). Cooperation and conflict: Field experiments in Northern Ireland. Proceedings of the Royal Society B: Biological Sciences, 281(1792), 20141435-20141435. https://doi.org/10.1098/rspb.2014.1435

Silver, E. (2020). Students' Attitudes Toward College Drinking: A Moral Intuitionist Approach. Deviant Behavior, 41(8), 1033-1051. https://doi.org/10.1080/01639625.2019.1596538

Silver, E., \& Silver, J. R. (2019). Morality and self-control: The role of binding and individualizing moral motives. Deviant Behavior, 1-20.

Singh, M. (2018). The cultural evolution of shamanism. Behavioral and Brain Sciences, 41. https://doi.org/10.1017/S0140525X17001893 
Singh, M. (2021). Magic, Explanations, and Evil: The Origins and Design of Witches and Sorcerers. Current Anthropology, 62(1), 2-29. https://doi.org/10.1086/713111

Singh, M. (2022). Subjective selection and the evolution of complex culture. Evolutionary Anthropology: Issues, News, and Reviews. https://doi.org/10.31234/osf.io/4t2ud

Singh, M., \& Henrich, J. (2020). Why do religious leaders observe costly prohibitions? Examining taboos on Mentawai shamans. Evolutionary Human Sciences, 2, e32. https://doi.org/10.1017/ehs.2020.32

Singh, M., Wrangham, R., \& Glowacki, L. (2017). Self-Interest and the Design of Rules. Human Nature, 28(4), 457-480. https://doi.org/10.1007/s12110-017-9298-7

Sjåstad, H. (2019). Short-sighted greed? Focusing on the future promotes reputation-based generosity. Judgment and Decision Making, 14(2), 199-213.

Slingerland, E. G. (2014). Trying not to try: The art and science of spontaneity (First Edition). Crown Publishers. Sloman, S. A., Fernbach, P. M., \& Ewing, S. (2009). Chapter 1 Causal Models: The Representational Infrastructure for Moral Judgment. In B. H. Ross (Ed.), Psychology of Learning and Motivation (Vol. 50, pp. 1-26). Academic Press. https://doi.org/10.1016/S0079-7421(08)00401-5

Sommer, M. H. (2000). Sex, law, and society in late imperial China. Stanford University Press.

Soutschek, A., Sauter, M., \& Schubert, T. (2015). The Importance of the Lateral Prefrontal Cortex for Strategic Decision Making in the Prisoner's Dilemma. Cognitive, Affective \& Behavioral Neuroscience, 15. https://doi.org/10.3758/s13415-015-0372-5

Spicer, K., \& Platek, S. (2010). Curvaceous female bodies activate neural reward centers in men. Communicative \& Integrative Biology, 3, 282-283. https://doi.org/10.4161/cib.3.3.11560

Spiegel, J. S. (2020a). Cultivating Self-Control: Foundations and Methods in the Christian Theological Tradition. Journal of Spiritual Formation and Soul Care, 13(2), 193-210. https://doi.org/10.1177/1939790920918881

Spiegel, J. S. (2020b). Cultivating Self-Control: Foundations and Methods in the Christian Theological Tradition. Journal of Spiritual Formation and Soul Care, 13(2), 193-210. https://doi.org/10.1177/1939790920918881

Stanford, P. K. (2018). The difference between ice cream and Nazis: Moral externalization and the evolution of human cooperation. Behavioral and Brain Sciences, 41, e95. https://doi.org/10.1017/S0140525X17001911

Steim, R. I., \& Nemeroff, C. J. (1995). Moral Overtones of Food: Judgments of Others Based on What they Eat. Personality and Social Psychology Bulletin, 21(5), 480-490. https://doi.org/10.1177/0146167295215006

Stephens, W. N. (1972). A Cross-Cultural Study of Modesty. Behavior Science Notes, 7(1), 1-28. https://doi.org/10.1177/106939717200700101

Sterckx, R. (Ed.). (2005). Of Tripod and Palate. Palgrave Macmillan US. https://doi.org/10.1057/9781403979278 
Stevens, J. R., Cushman, F. A., \& Hauser, M. D. (2005). Evolving the Psychological Mechanisms for Cooperation. Annual Review of Ecology, Evolution, and Systematics, 36(1), 499-518. https://doi.org/10.1146/annurev.ecolsys.36.113004.083814

Story, G. W., Vlaev, I., Seymour, B., Darzi, A., \& Dolan, R. J. (2014). Does temporal discounting explain unhealthy behavior? A systematic review and reinforcement learning perspective. Frontiers in Behavioral Neuroscience, 8. https://doi.org/10.3389/fnbeh.2014.00076

Strang, S., Gross, J., Schuhmann, T., Riedl, A., Weber, B., \& Sack, A. T. (2015). Be nice if you have toThe neurobiological roots of strategic fairness. Social Cognitive and Affective Neuroscience, 10(6), 790 796. https://doi.org/10.1093/scan/nsu114

Strassmann, B. I. (1992). The function of menstrual taboos among the dogon: Defense against Cuckoldry? Human Nature, 3(2), 89-131. https://doi.org/10.1007/BF02692249

Strassmann, B. I., Kurapati, N. T., Hug, B. F., Burke, E. E., Gillespie, B. W., Karafet, T. M., \& Hammer, M. F. (2012). Religion as a means to assure paternity. Proceedings of the National Academy of Sciences, 109(25), 9781-9785. https://doi.org/10.1073/pnas.1110442109

Stunkard, A., LaFleur, W., \& Wadden, T. (1998). Stigmatization of obesity in medieval times: Asia and Europe. International Journal of Obesity, 22(12), 1141-1144. https:// doi.org/10.1038/sj.ijo.0800753 Stylianou, S. (2004). The Role of Religiosity in the Opposition to Drug Use. International Journal of Offender Therapy and Comparative Criminology, 48(4), 429-448. https://doi.org/10.1177/0306624X03261253 Stylianou, S. (2010). Victimless Deviance: Toward a Classification of Opposition Justifications. 14.

Suiming, P. (1998). The Move Toward Spiritual Asceticism in Chinese Sexual Culture. Chinese Sociology \& Antbropology, 31(1), 14-24. https://doi.org/10.2753/CSA0009-4625310114

Sweeney, E. (2012). Aquinas on the Seven Deadly Sins: Tradition and Innovation. In R. G. N. S. J. Ridyard (Ed.), Sin in Medieval and Early Modern Culture: The Tradition of the Seven Deadly Sins. York Medieval Press/Boydell and Brewer.

Symons, D. (1995). Beauty is in the adaptations of the beholder: The evolutionary psychology of human female sexual attractiveness. Sexual Nature, Sexual Culture, 80-118.

Sznycer, D., Lopez Seal, M. F., Sell, A., Lim, J., Porat, R., Shalvi, S., Halperin, E., Cosmides, L., \& Tooby, J. (2017). Support for redistribution is shaped by compassion, envy, and self-interest, but not a taste for fairness. Proceedings of the National Academy of Sciences, 114(31), 8420-8425. https://doi.org/10.1073/pnas.1703801114

Tamir, C., Connaughton, A., \& Salazar, A. M. (2020). People's thoughts on whether belief in God is necessary to be moral vary by economic development, education and age. 39.

Tamney, J. B. (1980). Fasting and Modernization. Journal for the Scientific Study of Religion, 19(2), 129. https://doi.org/10.2307/1386247

Tamney, J. B. (1986). Fasting and Dieting: A Research Note. Review of Religious Research, 27(3), 255-262. JSTOR. https://doi.org/10.2307/3511420

Tentler, T. N. (2015). Sin and Confession on the Eve of the Reformation. Princeton University Press. 
Thielmann, I., Spadaro, G., \& Balliet, D. (2020). Personality and prosocial behavior: A theoretical framework and meta-analysis. Psychological Bulletin, 146(1), 30-90.

https://doi.org/10.1037/bul0000217

Tian, A. D., Schroeder, J., Häubl, G., Risen, J. L., Norton, M. I., \& Gino, F. (2018). Enacting rituals to improve self-control. Journal of Personality and Social Psychology, 114(6), 851-876. https://doi.org/10.1037/pspa0000113

Tierney, W., Hardy, J., Ebersole, C. R., Viganola, D., Clemente, E. G., Gordon, M., Hoogeveen, S., Haaf, J., Dreber, A., Johannesson, M., Pfeiffer, T., Huang, J. L., Vaughn, L. A., DeMarree, K., Igou, E. R., Chapman, H., Gantman, A., Vanaman, M., Wylie, J., .. Uhlmann, E. L. (2021). A creative destruction approach to replication: Implicit work and sex morality across cultures. Journal of Experimental Social Psychology, 93, 104060. https://doi.org/10.1016/j.jesp.2020.104060

Tiwald, J. (2020). Song-Ming Confucianism. In E. N. Zalta (Ed.), The Stanford Encyclopedia of Philosophy (Summer 2020). Metaphysics Research Lab, Stanford University. https://plato.stanford.edu/archives/sum2020/entries/song-ming-confucianism/

Tomasello, M. (2019). The Moral Psychology of Obligation. Behavioral and Brain Sciences, 1-33. https://doi.org/10.1017/S0140525X19001742

Tooby, J., \& Cosmides, L. (2010). Groups in mind: The coalitional roots of war and morality. Human Morality and Sociality: Evolutionary and Comparative Perspectives, 91-234.

Trivers, R. L. (1971). The evolution of reciprocal altruism. The Quarterly Review of Biology, 46(1), 35-57. Tybur, J. M., Lieberman, D., Kurzban, R., \& DeScioli, P. (2013). Disgust: Evolved function and structure. Psychological Review, 120(1), 65-84. https://doi.org/10.1037/a0030778

Uhlmann, E. L., Poehlman, T. A., Tannenbaum, D., \& Bargh, J. A. (2011). Implicit Puritanism in American moral cognition. Journal of Experimental Social Psychology, 47(2), 312-320. https://doi.org/10.1016/j.jesp.2010.10.013

van Gelder, J.-L., Hershfield, H. E., \& Nordgren, L. F. (2013). Vividness of the Future Self Predicts Delinquency. Psychological Science, 24(6), 974-980. https://doi.org/10.1177/0956797612465197 van Leeuwen, F., Koenig, B. L., Graham, J., \& Park, J. H. (2014). Moral concerns across the United States: Associations with life-history variables, pathogen prevalence, urbanization, cognitive ability, and social class. Evolution and Human Behavior, 35(6), 464-471.

https://doi.org/10.1016/j.evolhumbehav.2014.06.005

Vatuk, V. P., \& Vatuk, S. J. (1967). Chatorpan: A Culturally Defined Form of Addiction in North India. International Journal of the Addictions, 2(1), 103-113. https://doi.org/10.3109/10826086709074414

Vazsonyi, A. T., Mikuška, J., \& Kelley, E. L. (2017). It's time: A meta-analysis on the self-control-deviance link. Journal of Criminal Justice, 48, 48-63. https://doi.org/10.1016/j.jcrimjus.2016.10.001

Vengeliene, V., Bilbao, A., Molander, A., \& Spanagel, R. (2008). Neuropharmacology of alcohol addiction. British Journal of Pharmacology, 154(2), 299-315. https://doi.org/10.1038/bjp.2008.30 
Veyne, P. (1978). La famille et l'amour sous le Haut-Empire romain. Annales. Histoire, Sciences Sociales, 33(1), 35-63.

Volkow, N. D., Wang, G.-J., \& Baler, R. D. (2011). Reward, dopamine and the control of food intake: Implications for obesity. Trends in Cognitive Sciences, 15(1), 37-46. https://doi.org/10.1016/j.tics.2010.11.001

Volkow, N. D., Wise, R. A., \& Baler, R. (2017). The dopamine motive system: Implications for drug and food addiction. Nature Reviews Neuroscience, 18(12), 741-752. https://doi.org/10.1038/nrn.2017.130

Vonasch, A. J., Clark, C. J., Lau, S., Vohs, K. D., \& Baumeister, R. F. (2017). Ordinary people associate addiction with loss of free will. Addictive Behaviors Reports, 5, 56-66. https://doi.org/10.1016/j.abrep.2017.01.002

Vonasch, A. J., \& Sjåstad, H. (2021). Future-Orientation (as Trait and State) Promotes ReputationProtective Choice in Moral Dilemmas. Social Psychological and Personality Science, 12(3), 383-391. https://doi.org/10.1177/1948550619899257

Wagner, A. L. (1997). Adversaries of dance: From the Puritans to the present. University of Illinois Press.

Walzer, M. (1963). Puritanism as a Revolutionary Ideology. History and Theory, 3(1), 59-90. https://doi.org/10.2307/2504304

Walzer, M. (1982). The Revolution of the Saints: A Study in the Origins of Radical Politics. Harvard University Press.

Warner, J. (1997). Shifting categories of the social harms associated with alcohol: Examples from late medieval and early modern England. American Journal of Public Health, 87(11), 1788-1797.

Weafer, J., Mitchell, S. H., \& de Wit, H. (2014). Recent Translational Findings on Impulsivity in Relation to Drug Abuse. Current Addiction Reports, 1(4), 289-300. https://doi.org/10.1007/s40429-0140035-6

Weber, M. (1968). The Religion of China: Confucianism and Taoism. (New edition). The Free Press.

Weber, M. (2013). The Protestant Ethic and the Spirit of Capitalism. Routledge.

Weeden, J., Cohen, A. B., \& Kenrick, D. T. (2008). Religious attendance as reproductive support. Evolution and Human Behavior, 29(5), 327-334. https://doi.org/10.1016/j.evolhumbehav.2008.03.004

Weeden, J., \& Kurzban, R. (2013). What predicts religiosity? A multinational analysis of reproductive and cooperative morals. Evolution and Human Behavior, 34(6), 440-445. https://doi.org/10.1016/j.evolhumbehav.2013.08.006

Weeden, J., \& Kurzban, R. (2016). The Hidden Agenda of the Political Mind: How Self-Interest Shapes Our Opinions and Why We Won't Admit It. Princeton University Press.

Weiner, A. B. (1988). The Trobrianders of Papua New Guinea. Holt, Rinehart and Winston.

Weiss, A., Forstmann, M., \& Burgmer, P. (2021). Moralizing mental states: The role of trait self-control and control perceptions. Cognition. https://doi.org/10.1016/j.cognition.2021.104662 
Wells, S., \& Yao, P. (2015). Discourses on gender and sexuality. The Cambridge World History: Volume 4, A World with States, Empires and Networks 1200 BCE-900 CE.

West, S. A., Cooper, G. A., Ghoul, M. B., \& Griffin, A. S. (2021). Ten recent insights for our understanding of cooperation. Nature Ecology \& Evolution, 5(4), 419-430. https://doi.org/10.1038/s41559-020-01384-x

West, S. A., El Mouden, C., \& Gardner, A. (2011). Sixteen common misconceptions about the evolution of cooperation in humans. Evolution and Human Behavior, 32(4), 231-262. https://doi.org/10.1016/j.evolhumbehav.2010.08.001

West, S. A., Griffin, A. S., \& Gardner, A. (2007). Social semantics: Altruism, cooperation, mutualism, strong reciprocity and group selection. Journal of Evolutionary Biology, 20(2), 415-432. https://doi.org/10.1111/j.1420-9101.2006.01258.x

Whitehead, A. L., \& Perry, S. L. (2018). Unbuckling the Bible belt: A state-level analysis of religious factors and Google searches for porn. The Journal of Sex Research, 55(3), 273-283.

Wiessner, P., \& Tumu, A. (1998). Historical vines: Enga networks of exchange, ritual and warfare in Papua New Guinea. Smithsonian Inst Press.

Wilson, M., \& Daly, M. (2004). Do pretty women inspire men to discount the future? Proceedings of the Royal Society of London. Series B: Biological Sciences, 271(suppl_4). https://doi.org/10.1098/rsbl.2003.0134

Wood, C. (2017). Ritual well-being: Toward a social signaling model of religion and mental health. Religion, Brain \& Behavior, 7(3), 223-243. https://doi.org/10.1080/2153599X.2016.1156556

Yamagishi, T., Matsumoto, Y., Kiyonari, T., Takagishi, H., Li, Y., Kanai, R., \& Sakagami, M. (2017). Response time in economic games reflects different types of decision conflict for prosocial and proself individuals. Proceedings of the National Academy of Sciences, 114, 201608877. https://doi.org/10.1073/pnas.1608877114

Yang, L. H., Wong, L. Y., Grivel, M. M., \& Hasin, D. S. (2017). Stigma and substance use disorders: An international phenomenon. Current Opinion in Psychiatry, 30(5), 378-388. https://doi.org/10.1097/YCO.0000000000000351

Yaple, Z. A., \& Yu, R. (2020). Functional and Structural Brain Correlates of Socioeconomic Status. Cerebral Cortex, 30(1), 181-196. https://doi.org/10.1093/cercor/bhz080

Yeomans, H. (2011). What Did the British Temperance Movement Accomplish? Attitudes to Alcohol, the Law and Moral Regulation. Sociology, 45(1), 38-53. https://doi.org/10.1177/0038038510387189

Yü, Y. (2021). The Religious Ethic and Mercantile Spirit in Early Modern China. Columbia University Press. https://doi.org/10.7312/yu-20042

Zwirner, E., \& Raihani, N. (2020). Neighbourhood wealth, not urbanicity, predicts prosociality towards strangers. Proceedings of the Royal Society B: Biological Sciences, 287(1936), 20201359. https://doi.org/10.1098/rspb.2020.1359 
